\title{
Models for Translational Proton Radiobiology-From Bench to Bedside and Back
}

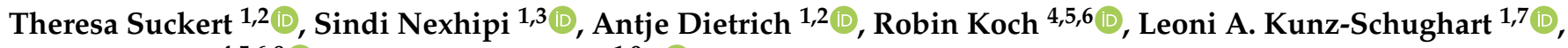 \\ Emanuel Bahn 4,5,6,8 (D) and Elke Beyreuther 1,9,*iD
}

check for updates

Citation: Suckert, T.; Nexhipi, S.; Dietrich, A.; Koch, R.;

Kunz-Schughart, L.A.; Bahn, E.; Beyreuther, E. Models for Translational Proton Radiobiology-From Bench to Bedside and Back. Cancers 2021, 13, 4216. https://doi.org/10.3390/ cancers13164216

Academic Editor: Samuel Cos

Received: 14 July 2021

Accepted: 17 August 2021

Published: 22 August 2021

Publisher's Note: MDPI stays neutral with regard to jurisdictional claims in published maps and institutional affiliations.

Copyright: (c) 2021 by the authors. Licensee MDPI, Basel, Switzerland. This article is an open access article distributed under the terms and conditions of the Creative Commons Attribution (CC BY) license (https:/ / creativecommons.org/licenses/by/ $4.0 /)$.
1 OncoRay-National Center for Radiation Research in Oncology, Faculty of Medicine and University Hospital Carl Gustav Carus, Technische Universität Dresden, Helmholtz-Zentrum Dresden-Rossendorf, 01309 Dresden, Germany; theresa.suckert@uniklinikum-dresden.de (T.S.);

sindi.nexhipi@uniklinikum-dresden.de (S.N.); Antje.Dietrich@uniklinikum-dresden.de (A.D.); leoni.kunz-schughart@oncoray.de (L.A.K.-S.)

2 German Cancer Consortium (DKTK), Partner Site Dresden, and German Cancer Research Center (DKFZ), 69120 Heidelberg, Germany

3 Helmholtz-Zentrum Dresden-Rossendorf, Institute of Radiooncology-OncoRay, 01309 Dresden, Germany

4 Heidelberg Institute of Radiation Oncology (HIRO), 69120 Heidelberg, Germany; robin.koch@dkfz-heidelberg.de (R.K.); e.bahn@dkfz-heidelberg.de (E.B.)

5 Department of Radiation Oncology, Heidelberg University Hospital, 69120 Heidelberg, Germany

6 National Center for Tumor Diseases (NCT), 69120 Heidelberg, Germany

7 National Center for Tumor Diseases (NCT), Partner Site Dresden, 01307 Dresden, Germany

8 German Cancer Research Center (DKFZ), Clinical Cooperation Unit Radiation Oncology, 69120 Heidelberg, Germany

9 Helmholtz-Zentrum Dresden-Rossendorf, Institute of Radiation Physics, 01328 Dresden, Germany

* Correspondence: elke.beyreuther@uniklinikum-dresden.de

Simple Summary: An increasing number of cancer patients are treated with proton therapy. Nevertheless, there are still open questions that require preclinical studies, for example, those regarding long-term side effects or new treatment approaches. In this review, we discuss the main research topics of proton radiobiology and describe the typical challenges related to preclinical experiments in this field. We provide a summary of the different available preclinical models, and how they were applied to conduct proton-specific research in the past. This includes cell culture models of increasing complexity, animal studies, and computer simulations. In addition, we give an overview of possible endpoints and suggest models from other disciplines for adaptation to biomedical proton research. In doing so, we contribute to designing meaningful research studies in the future, which will ultimately help to improve patient treatment.

Abstract: The number of proton therapy centers worldwide are increasing steadily, with more than two million cancer patients treated so far. Despite this development, pending questions on proton radiobiology still call for basic and translational preclinical research. Open issues are the on-going discussion on an energy-dependent varying proton RBE (relative biological effectiveness), a better characterization of normal tissue side effects and combination treatments with drugs originally developed for photon therapy. At the same time, novel possibilities arise, such as radioimmunotherapy, and new proton therapy schemata, such as FLASH irradiation and proton mini-beams. The study of those aspects demands for radiobiological models at different stages along the translational chain, allowing the investigation of mechanisms from the molecular level to whole organisms. Focusing on the challenges and specifics of proton research, this review summarizes the different available models, ranging from in vitro systems to animal studies of increasing complexity as well as complementing in silico approaches.

Keywords: proton therapy; proton RBE; toxicity; preclinical models; cell culture; organoids; tissue slice culture; mouse model; zebrafish; in silico modeling 


\section{Introduction}

Proton therapy has an inverse depth dose profile when compared to conventional radiotherapy with photons, which offers the possibility to reduce the dose delivered to the tumor-surrounding normal tissue. In long-term survivors, this dosimetric benefit can increase the quality of life [1] by decreasing the risk of normal tissue side effects [2-4]. For this reason, the number of proton beam facilities has been steadily rising in the last decade, with several new ones planned or already under construction [5]. To date, more than two million cancer patients have been treated with proton therapy [5]. Nevertheless, numerous open questions on basic radiobiology, physical effects, novel therapeutic strategies, and technical innovations have remained unanswered, calling for intensified efforts in translational research.

A topic of ongoing discussion is the proton relative biological effectiveness (RBE), which is assumed to be a constant factor of 1.1 in the clinical context. However, abundant in vitro, rare in vivo (summarized in [6]), and first clinical [7-10] data indicate a varying RBE, often with a distinct elevation at the distal end of the proton range. Several concepts exist for RBE-adapted treatment planning in clinical practice [11-13], but there is a considerable variation within the experimental data. RBE values strongly depend on different physical (dose, dose rate, linear energy transfer (LET), fractionation) and biological (tissue, model, endpoint) factors [13-15]. These issues call for caution regarding clinical implementation of a varying RBE and create the need for more preclinical studies, using sophisticated in vitro systems and in vivo models [13,16].

The suspected variable RBE, and other factors, such as proton range uncertainties or anatomical changes during treatment [17], can result in dose deviations and consequential normal tissue side effects in some patients. Moreover, organ-specific radiosensitivities may differ from clinical guidelines. For example, there are indications of an increased radiosensitivity in the periventricular region, leading to a higher incidence of radiationinduced brain injury $[10,18]$. Out-of-field effects have also been observed, especially after irradiation of larger volumes [19]. Thus, these normal tissue toxicities require further research in order to adapt clinical guidelines for optimal patient outcomes.

While normal tissue sparing is the main advantage of proton therapy, the radiation response of the tumor has to be considered as well. Differences between photon and proton irradiation in deoxyribonucleic acid (DNA) damage induction and repair are still being unraveled [20]. In addition, there are indications that particle irradiation not only influences cancer cell migration and invasion [21-23], but also does so differently from photon irradiation [24]. These differential responses may influence treatment outcomes, especially in chemoradiotherapy settings. Furthermore, new opportunities for combinatorial targeted therapies or radioimmunotherapy [25] are emerging that require experimental validation. In the field of proton therapy, research activities not only focus on biological mechanisms and new clinical strategies, but also need to aim for technical improvements and novelties. Examples for the latter are innovative beam delivery concepts, such as FLASH irradiation $[26,27]$ or proton minibeams [28,29], both of which promise increased normal tissue protection. However, the mode of action of these modalities and their optimal treatment parameters are not yet fully understood and require systematic studies.

The above-mentioned research questions cover a large variety of topics; yet, their common denominator is the requirement of suitable preclinical models to complement or precede clinical trials. The preclinical setting enables the investigation of radiation effects on a molecular, cellular, and systemic level, which contributes to our understanding of the underlying mechanisms. In addition, aspects such as the safety and effectiveness of new treatment approaches can be tested before designing clinical studies. A prerequisite in translational research is clinical relevance. This does not mean that the most complex model and experimental setup, i.e., an in vivo study, is always necessary, but rather the one most suitable for the research question at hand. For example, patient-derived three-dimensional (3D) cell culture models can yield more significant results than animal experiments, and in silico methods can help to make efficient experimental design decisions in conventional 
biological studies. In this context, our review summarizes the existing preclinical models for proton therapy research, highlights examples for their application, and offers conclusions on useful experimental endpoints. We particularly emphasize restrictions and challenges in the field of proton radiobiology and discuss how they can be overcome to gain the most relevant insights for clinical implementation.

\section{Characteristic Challenges in Preclinical Proton Research}

\subsection{The Physicist's Point of View}

The performance of proton experiments faces several challenges that might influence the choice of model and endpoint. Access to proton facilities, one of the main bottlenecks in former times, has clearly improved in the last years with newly operating proton therapy facilities that include dedicated experimental areas, e.g., [30,31], allowing for radiobiology and physics experiments in parallel to patient treatment. Focusing on collaborations and scientific exchange, the Inspire project of the European Union provides a network and transnational access program between European proton facilities, clinical and research ones, that enable radiobiology experiments [32]. Clinical proton centers are organized under the umbrellas of the globally active Particle Therapy Co-Operative Group (PTCOG) [5] and the European Particle Therapy Network (EPTN).

Currently, systematic proton studies face two main challenges: (1) the precise and reproducible positioning of samples, and (2) accurate absolute dosimetry, especially for small volumes and at the distal edge. These two issues cannot be considered independently since sample positioning along the proton depth dose curve defines the necessary corrections for beam quality [33] and LET [34], which have to be taken into account by dosimetry. Thereby, preclinical dosimetry refers, in principle, also to clinical dosimetry standards but differs in details, such as the composition and dimensions of materials in the beam path [35] and the size of the target volumes. For adherent cellular monolayers, which are typically only a few microns thick, positioning is straightforward and can be realized with high accuracy using water phantoms [30] or water equivalent material [36,37] for range compensation. In combination with dose simulations, these approaches allow, for example, the determination of cell survival data dependent on proton LET [36,37]. The irradiation of 3D cultures is more complicated, especially at horizontal beam lines that demand for the upright positioning of samples. Spheroids, for example, roll down the agarose bed if the culture vessel is tilted to $90^{\circ}$; this has to be taken into account for positioning and dosimetry. Organ slices and 3D cultures in gelatinous matrices cannot be irradiated upright and should, therefore, be investigated at vertical proton beams [38] or require dedicated irradiation setups $[39,40]$.

Unlike in vitro studies, in vivo ones include the irradiation of different volumesfrom whole organs [41] and extended tumor volumes to subvolumes of organs and small orthotopic tumor models-depending on the research question. Here, precise and reproducible positioning is key, especially for $3 \mathrm{D}$ targets inside the animal body. Elaborated positioning for animal experiments is realized at the different proton centers [31,42-48], which is, however, difficult to standardize. In a first attempt, Gerlach et al. developed a portable setup for animal studies with protons [46]; some facilities installed small animal irradiators, enabling in situ CT imaging and precise positioning of target volumes $[49,50]$. Besides positioning, small animals are also challenging for absolute dosimetry, due to a lack of standardized dosimeters for such volumes. Practical solutions are small dosimeters, such as alanin pellets, and radiochromic films that can be cut into user-defined shapes and sizes [51-53]. Experiments with new radiation qualities, such as FLASH radiotherapy, laser-driven sources or proton mini-beams, demand for adapted solutions with respect to sample positioning and dosimetry [54-57]. Moreover, point-like measurements with small dosimeters can be supported by simulations [58] to resolve proton dose distributions $[59,60]$. Standardized 3D phantoms of rodents could clearly improve preclinical proton dosimetry, but are currently only available for orthovoltage X-rays [61]. 
On a final note, it should be mentioned that the correct reporting of all these physical beam and proton field parameters has acquired an increased importance during the last years [62-64]. Several expert groups have released recommendations on profound reporting for preclinical proton experiments, for example, the ESTRO-Advisory Committee for Radiation Oncology Practice [65].

\subsection{The Biologist's Point of View}

In recent years, medical research had to cope with the so-called "reproducibility crisis": scientists report that they are not able to reproduce experiments [66], and breakthroughs from preclinical research fail to deliver the hoped-for clinical impact. For example, many promising novel cancer drugs that had proven effective in preclinical studies failed in clinical trials $[64,67]$. Considerable contributors to the problem are poor methods reporting and low statistical power of experimental designs [66]. Another aspect is that the chosen experimental model(s) and readouts often neither adequately reflect the selected clinically relevant endpoints nor represent the clinical reality [67]. Accordingly, state-of-the-art preclinical proton therapy testing needs well-defined experimental settings to avoid a similar waste of time and resources and to not slow down the overall progress needed to improve patient treatment.

The requirements for optimal preclinical models are high. First and foremost, the transferability to patients needs to be ensured as far as possible. Other essential factors are financial affordability, reasonable throughput, reproducibility, and the availability of relevant experimental endpoints. While all preclinical studies have to deal with these restrictions, proton radiobiology is additionally challenged by the assignment of beam time. At both clinical and experimental proton accelerators, the available beam time for radiobiological experiments is limited, which demands meticulous preparations, including the choice of suitable models and readouts. If cells or tumor models are not growing at the anticipated speed or if a technical failure occurs, simple postponing of the experiment is often not possible. Hence, physicists and biologists need to work hand in hand in proton radiobiology to optimize the experiments for maximum output. This includes not only careful preparation of and support during the experiment, but also the comprehensive in silico description of the experimental setup, model and results. What appears to be challenging and work-intense is at the same time beneficial since the close interdisciplinary collaboration opens completely new and innovative research approaches. For example, radiobiological data can be described and simulated very well under physical aspects; thus, in silico experiments can contribute vastly to our current understanding.

The following chapters describe the available models and respective endpoints applicable in proton radiobiology along the translational chain from two-dimensional (2D) and 3D cell culture to small animals, large mammals and in silico concepts (Figure 1) The advantages and disadvantages of each approach are briefly discussed, along with examples of its successful application and recommendations for optimal use. For clarity and synopsis, the respective models, as well as their specifics and a few representative endpoints are outlined at the beginning of each chapter. 


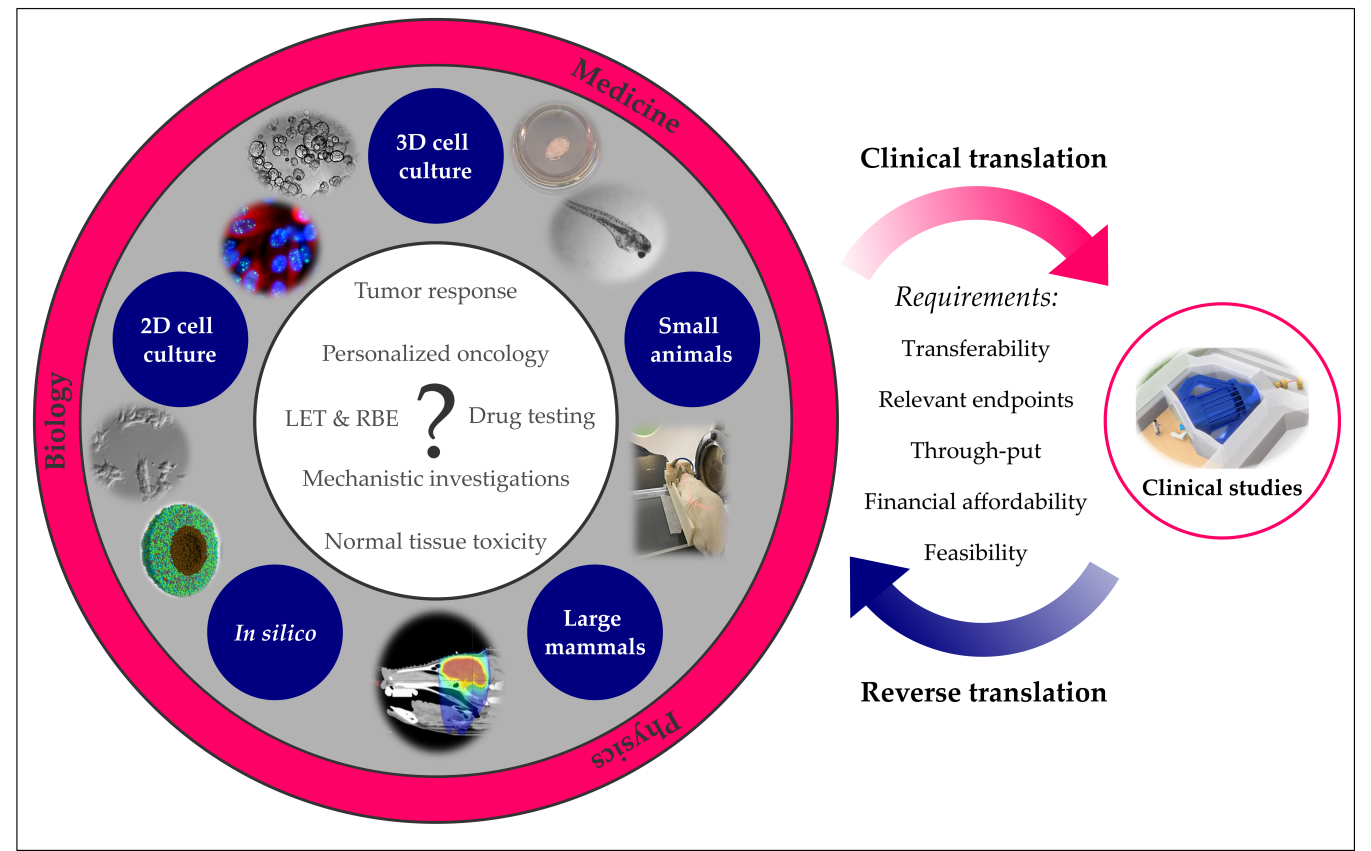

Figure 1. Translational research in (proton) radiobiology. Proton-specific research questions can be answered with a variety of preclinical models ranging from 2D cell culture to higher mammals. In silico approaches may deepen the understanding of underlying mechanisms. Preclinical insights can help to design clinical studies, and clinical observations can be back-translated into preclinical models. Images (clockwise): Tumor slice culture [39], irradiated zebrafish embryo [68], rat proton irradiation setup at Institut Curie [32], photon treatment plan of a mini-pig brain [69], simulated tumor spheroid 40 min post photon irradiation [70], migrating human uveal melanoma cells [22], fluorescence staining of HeLa cells [71], human pancreatic cancer organoids (courtesy of Max Naumann).

\section{In Vitro Cell Culture Models}

This chapter provides an overview of the different cell culture models that were currently or might in future be used in proton radiobiology. As summarized in the graphical outline (Figure 2), the models are presented from the less complex 2D cell culture to spheroids, organoids and more complex 3D models.

\begin{tabular}{|c|c|c|c|c|}
\hline & Cell monolayer & Spheroids & Organoids & Other 3D models \\
\hline Dimensions for irradiation & $10-100 \mu \mathrm{m}$ & $<1500 \mu \mathrm{m}$ & $<600 \mu \mathrm{m}$ & $150-600 \mu \mathrm{m}$ \\
\hline Model specifics & $\begin{array}{l}\text { Established cell lines } \\
\text { Primary cells }\end{array}$ & $\begin{array}{l}\text { Derived from cell lines } \\
\text { or primary cells } \\
\text { Tumor or co-cultures }\end{array}$ & $\begin{array}{l}\text { Patient- or mouse derived } \\
\text { Tumor or normal tissue }\end{array}$ & $\begin{array}{l}\text { Thin-cut tissue slices } \\
\text { (tumor or organs) } \\
\text { 3D scaffolds } \\
\text { organs-on-a-chip }\end{array}$ \\
\hline \multirow[t]{2}{*}{ Representative endpoint } & Cellular survival & $\begin{array}{l}\text { Spheroid control } \\
\text { probability }(\mathrm{SCP})\end{array}$ & Cell viability & Histology \\
\hline & & & & Complexity \\
\hline
\end{tabular}

Figure 2. Overview of in vitro models for proton radiobiology experiments. Images (left to right): migrating human uveal melanoma cells [22], fluorescence staining of a tumor spheroid [72], human pancreatic cancer organoids (courtesy of Max Naumann), tumor slice culture [39]. Dimension refers to the required beam path length for irradiating the respective model. 


\subsection{D Cell Culture}

The 2D cell culture is an extensively used in vitro model. Both primary and established cell lines are simple and economical tools used to investigate various aspects of radiobiology. Primary cell lines are more reflective of the in vivo genetic features, as they are isolated directly from human or animal tissue [73]. Established cell lines, however, are applied more frequently because of their infinite lifespan, known characteristics, standardized culturing, and ease of genetic manipulations. Moreover, the usage of established cell lines circumvents ethical concerns associated with the use of animal and human specimens [74]. In radiotherapy research, cell survival is a standard biological endpoint quantified by the colony formation assay (clonogenic survival assay). Other endpoints, such as apoptosis [75,76], reactive oxygen species [76], chromosome aberrations [77], the quantification of DNA damage and repair proteins, as well as the resulting gene expression changes [20,78-82], are studied to obtain a more detailed insight into radiation response mechanisms [14].

Established 2D cell lines play a pivotal role in the radiobiological characterization of proton irradiation. They are applied for comparing different proton facilities [83] and the evaluation of new treatment modalities, such as proton monoenergetic arc therapy [84], intensity-modulated proton therapy [85,86], spot-scanning proton therapy [87] and FLASH irradiation [78]. Well-known cell lines in this respect are V79 [88,89], derived from hamster lung fibroblasts, as well as human cell lines, such as H460 (large-cell lung carcinoma), HSG (human salivary gland tumor) [83,90], and normal human fibroblasts $[78,91]$, which are more relevant for patient treatment. Once established at a facility, these cell lines are frequently applied to study proton related effects, such as RBE [14], oxygen enhancement ratio [90], and LET. Generally, 2D cell cultures are the preferred model in LET studies since adherent cell monolayers of a few microns in thickness allow for a high positioning accuracy [36,37], unattainable in 3D cell culture or animal models [45]. For this purpose, various murine and human tumor [20,37,92], and normal tissue cell lines are used (summarized in [14]). The effect of LET and RBE in fractionated proton exposure has been studied in human fibroblasts [36]; however, the fractionation effects are still scarcely researched.

Additionally, 2D cell cultures are appropriate tools to investigate the radiation response of cells to different treatment modalities. Several studies have focused on the effect of proton irradiation on disease mechanisms, such as tumor invasion and migration for skin [22,24], brain [21], lung [93], and breast cancer [94-97]. Others have investigated how cells respond to different drugs, which is of the utmost importance in (proton) radiooncology, where chemoradiotherapy is a standard therapy approach. In clinical practice, treatment protocols of photon-concurrent chemotherapy are simply transferred to proton therapy, neglecting potential differences between these approaches [98]. As such, 2D cell culture can test the radiosensitizing effects of available chemotherapeutic agents $[99,100]$ and other drugs [101] in combination with proton irradiation on a range of cancer types. Screening platforms of well-known human tumor cell lines with heterogeneous genomes that mimic inter-patient variability are used to identify chemoradiotherapy susceptibility after photon irradiation [102,103] and should be extended to translational proton therapy approaches. Prospective markers and radiosensitivity genes can also be validated and studied in genetically modified cell lines in order to investigate radiation responses. As an example, a study showed that FANCD2 knockdown cell lines were more sensitive to proton rather than X-ray irradiation [104].

The advantages and wide applications of established 2D cell lines should be considered on a study-specific level. When chosen as a model, attention needs to be paid to the fact that they grow in a monolayer and, therefore, cannot mimic the complex in vivo tissue architecture and microenvironment. This hinders interpretation of both the tumor and normal tissue results for which therapy responses may depend on the vascularization and the $3 \mathrm{D}$ structure that provides different access to nutrients, oxygen, and therapeutic agents. 
Moreover, elaborated biological mechanisms, such as the progression of organ-specific early and late effects [14], demand more complex models.

\subsection{Spheroids and Organoids}

The $3 \mathrm{R}$ principles, i.e., replacement, reduction and refinement of animal experiments [105], continue to gain in importance across all scientific disciplines, including translational research, which has led to an increased interest in intricate and relevant in vitro models. In this regard, it is beyond dispute that $3 \mathrm{D}$ cultures are more realistic and informative than 2D cell systems [106-109]. The most straightforward approach in radiobiology is the 3D clonogenic survival assay, in which single cells grow into 3D cell clusters when cultured in extracellular matrix components [107,110,111]. More complex 3D structured models, such as multicellular spheroids, further reestablish histomorphological, pathophysiological, and microenvironmental features that better resemble the in vivo situation $[106,109,112,113]$. Their main characteristics depend on the size and can include 3D cell-cell and cell-matrix interactions, radial gradients of oxygen, nutrients, $\mathrm{pH}$, catabolites, cellular proliferative activity, and in vivo-like differentiation patterns; they can develop therapeutically-relevant hypoxic regions and a secondary necrotic core [106,113-117]. Another level of complexity is achieved by establishing patient-derived organoids from normal and tumor tissues of various entities [118-123]. They are considered the culture models closest to the individual patient, mirroring the heterogeneity and genetic background of the original tissue $[124,125]$. Organoids can also be grown from mouse tissue, which opens a wide range of possibilities for biological studies, including the use of transgenic donors [126,127]. However, some research questions call for even higher complexity mirrored by the co-culturing of multicellular spheroids or organoids with various stromal cell types, such as fibroblasts, endothelial, or hematopoietic cells [128-131].

From the radiobiological perspective, 3D cell cultures have already proven to be the most valuable tools. The work with 3D models has contributed to understanding the altered responsiveness of chronically hypoxic tumor cells, and the role of cell-cell and cell-matrix interactions in radioresistance $[106,109,112,116,132]$. The 3D clonogenic survival assay was recently applied for RBE studies with protons and carbon ions [40,111], and to evaluate the outcome of novel molecular targeted agents in combinatorial treatments for pancreatic and HNSCC cell line models [40,133]. A review from Walenta and Mueller-Klieser [134] summarizes the experimental studies from 2D and 3D cultures dedicated to evaluating the RBE and side effect mechanisms of heavy-charged particles. Multicellular spheroids were also applied to study proton irradiation alone [135] and in combination with chemotherapy $[136,137]$, to compare the RBE of spot scanning and passive scattering beams [138], and to validate the biological effectiveness of proton FLASH irradiation [139]. Furthermore, Brack et al. recently proved the technical feasibility of their irradiation device with laserdriven particles by visualizing DNA damage in a spheroid model [72]. Organoids derived from stem or progenitor cells are of utmost relevance for investigating normal tissue side effects, as they allow for stem cell-related response studies [125]. Normal tissue organoids, originating from, for example, the intestinal system, the salivary glands, or the mammary glands, were used to assess tissue radiation sensitivity and irradiation-induced toxicity mechanisms [127,140-142]. These models should be exploited in more detail to shed further light on the biological consequences of proton irradiation in normal tissues. In this context, it was shown that a magnetic field does not modify the response to proton irradiation in stem cell-derived salivary gland organoids [143]. Another impressive example is the study of Nowrouzi et al., who evaluated the gastro-intestinal response to photon, proton, and carbon ion radiation using transcriptome profiling of irradiated patient-derived human intestinal organoids [38]. Nowadays, studies in the field of tumor organoid-based personalized medicine more frequently consider radiation therapy (RT) [123,144-146]. Although trials using cancer-derived organoids treated with particle therapies are still lacking, they will soon inform decisions in the field. As proton therapy cannot be offered to all patients, there is a need for stratification. Here, patient-derived organoids represent a powerful 
tool for individualized treatment decisions [122,128]. Future trials should include pairs of normal and cancer tissue-derived organoids from the same patient to evaluate the full range of individual therapeutic windows $[125,128]$.

Notably, the experimental design and analytical endpoints used in 3D culture assays can critically differ, thereby defining the grade of in vivo resemblance. Most 3D clonogenic assays are based on the irradiation of single cells [110,111,147], which is still artificial because direct cell-cell interactions and some radiotherapeutically relevant (patho)physiological phenomena are not present during exposure. On the other hand, the assessment of clonogenic survival of irradiated cell clusters, spheroids, or organoids requires dissociation of the cultures upon treatments and subsequent seeding of single-cell suspensions. What appears to be a straightforward approach can become quite vulnerable to artifacts because different treatments may affect the cells' susceptibility to enzymatic and mechanical dissociation stress. Alternatively, cell viability assays adapted from classical drug response assays $[135,148]$ can be applied to monitor the metabolic activity of 3D cultures after treatment, as is often used in clinical trials with organoid cultures $[123,144,145]$. However, the results critically depend on the time of measurement and may not be suitable for all types or sizes of 3D cultures. Moreover, such endpoints do not reflect clonogenic survival, which is still considered one of the most important in vitro readouts in radiobiology. One promising method for assessing the treatment outcome remains image-based monitoring of 3D cultures over time. It allows visualizing culture integrity and subsequently determining volume growth kinetics, e.g., in spheroid growth delay studies $[115,137,149]$ or patient-derived organoids [144]. The state-of-the-art spheroid control probability assay represents a clinically relevant endpoint for experimental radiotherapy [149-152], analogous to the tumor control probability (TCP) and tumor control dose 50\% (TCD50) assessment in vivo [153]. Such analytical endpoints are essential for curative treatments and show great potential for systematic proton irradiation studies [136]. Furthermore, radiobiologists are encouraged to adopt some assays from sphere and spheroid cultures to organoid cultures. However, ongoing efforts are required to translate these long-term outcomes into clinically relevant endpoints that can be assessed more rapidly in organoids for screening purposes and personalized (proton) radiotherapy, for example, based on DNA damage analysis for assessing radiation sensitivity $[111,154,155]$.

\subsection{Thin-Cut Tissue Slices and Other 3D Cell Culture Models}

Another cell culture model offering 3D architecture is thin-cut tissue slices, which grow on specialized inserts at the interface of the medium and air. Both tumors and normal tissues can be cultured in this fashion. The former derive from either tumor-bearing animals or patients using surgical resections, whereas the latter mainly stem from rodents. The most widely used normal tissue in slice culture is the neonatal brain [156] but others, such as lung [157] or heart [158] slice cultures, exist as well.

Tissue slices offer several advantages compared to other cell culture systems, such as realistic heterogeneity, preserved tissue morphology, and high success rate during culture generation [159]. Therefore, they have been applied in RBE investigations [160], pharmacodynamic profiling [161], the testing of novel treatment compounds [162], and comparing different chemoradiotherapy combinations [163]. In addition, researchers examined the tumor microenvironment and cell invasion processes in tissue slices. Both thin-cut tumor slices alone [164] and co-culture systems of tumor cells and organotypic slices [165,166] were applied for such studies. Tumor slice culture in particular is considered a suitable tool for personalized medicine, enabling the comparison of treatment approaches prior to therapy for optimized patient outcome [162-164,167]. Relevant radiobiological endpoints for thin-cut tissue slices include the analysis of apoptosis, [160,163], proliferation [168], and DNA damage $[39,162,168]$. In addition, some functional assays exist that measure metabolism or cell death in slice cultures $[39,167,169]$. However, in contrast to spheroids and organoids, no data on tumor control probability rates can be achieved with this model. Other drawbacks are a limited culturing time, missing vasculature, as well as undesired 
functional and transcriptional changes during culturing $[159,170]$. So far, only a few studies have applied thin-cut slices as ex vivo platform for particle therapy with protons [39] or heavier ions $[160,163,168]$. Nevertheless, all above-mentioned experiments can be easily adapted for preclinical proton experiments; with the growing need for implementing the 3R principles, their number will likely increase.

While most radiobiology research has been performed on simpler 3D models such as spheroids, some studies are applying complex tissue-engineered approaches, such as 3D scaffolds or organs-on-a-chip. These models are often commercially available, thus potentially offering higher reproducibility across laboratories. Strikingly, particle experiments so far have all focused on different skin models, which were used to investigate proton RBE [171], normal tissue side effects of proton microchannel therapy [172], and LET-effects of carbon irradiation [173]. Despite promising results, these models are still rarely applied in preclinical proton research due to their high costs. With more suppliers on the market, this may change in the future.

On a final note, organ-on-a-chip applications may offer solutions to many abovementioned drawbacks of other cell culture models. They enable the investigation of both tumor and normal tissues, including the microenvironment, cell-cell interactions, and even organ functions [174]. Unfortunately, data on particle irradiation of organ-on-a-chip systems are not available yet, but first radiobiological applications are promising $[175,176]$.

\section{In Vivo Models}

This chapter summarize the in vivo models that were applied in proton research from the small teleost vertebrates, to rodents and rabbits, and finally larger mammals like cats, dogs, pigs and apes. Common specifics of these models as well as some representative endpoints are shown in Figure 3.

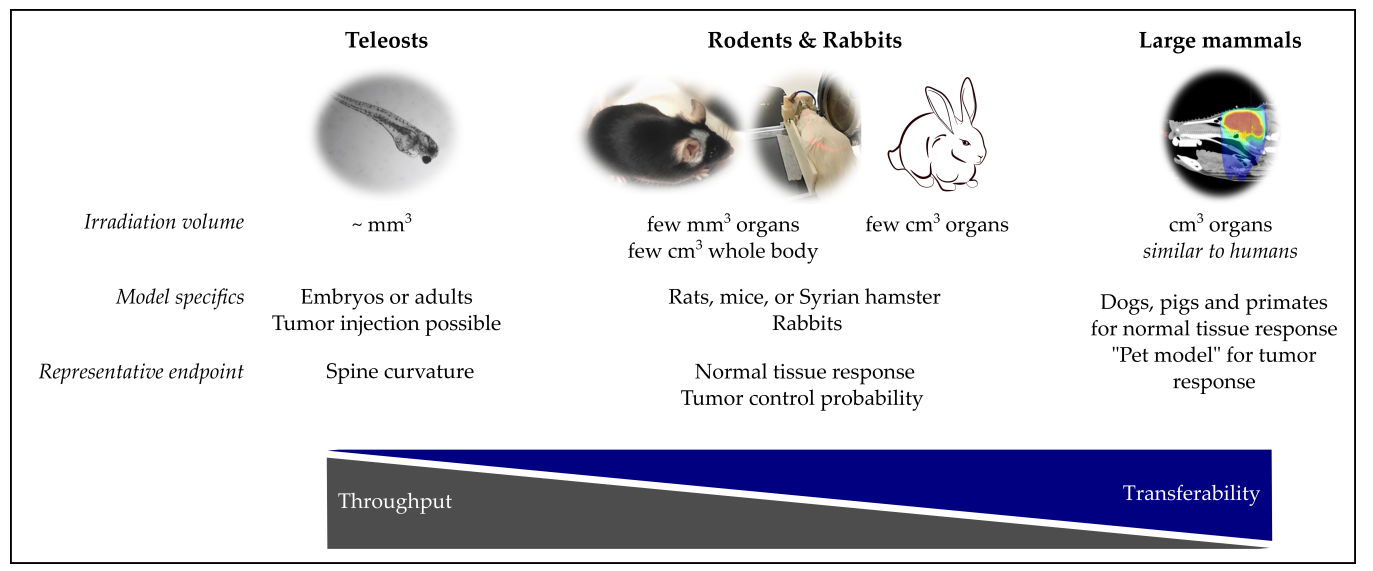

Figure 3. Overview of in vivo models for proton radiobiology experiments. Images (left to right): Irradiated zebrafish embryo [68], C57BL/6 mouse after proton brain irradiation [59], rat proton irradiation setup at Institut Curie [32], rabbit photon treatment plan of a mini-pig brain [69].

\subsection{Teleosts}

During the last years, the interest in zebrafish (Danio rerio) and medaka (Oryzias latipes) as small animal models has steadily increased, also for radiobiological research $[177,178]$. Both teleosts produce embryos in a transparent chorion, enabling easy detection of morphological malformations [68,179] by light microscopy. Extracorporeal embryonic development and whole genome sequencing facilitates genetic manipulation $[177,180]$, compared to mammals. Moreover, their fast development and a high number of embryos per breeding pair make teleosts attractive for systematic studies, e.g., those on radiation effects $[68,181,182]$ or combined treatment modalities $[179,183]$. Regarding proton research, the small size of the embryos of $1 \mathrm{~mm}$ in diameter one day after fertilization allows for irradiation in cell culture vessels and accurate positioning [68,181]. For example, Szabo et al. [68] used zebrafish embryos to determine the RBE of entrance and spread-out Bragg peak protons relative to a 
$6 \mathrm{MV}$ photon beam, whereas Li et al. [181] evaluated the response to $8 \mathrm{MeV}$ protons. More recently, zebrafish embryos became attractive to evaluate new proton radiation modalities, such as FLASH irradiation [184]. Adaptive response to proton microbeams [185] and altered blood vessel formation after proton irradiation [186] are two endpoints studied in adult zebrafish.

One step further, the injection of tumor cells enables the real-time and visual observation of tumor cell metastasis in zebrafish embryos $[187,188]$. The successful implementation of gastric [189] and colorectal [187] patient-derived xenograft (PDX) tumors resulted in the idea of using zebrafish as "avatars" for personalized medicine [190,191]. However, besides all advantages and possibilities, one should not forget that fish and mammals differ in many points, which might also affect radiation susceptibility and the treatment response. Following the translational chain, findings in teleosts should always be verified in mammals.

\subsection{Rodents}

Murine models, i.e., mice and rats, are conventionally considered the final link in the translational process to move forward from preclinical findings to clinical trials. Their advantages over large animal models are the small size, which facilities housing, lower economical expenses, as well as short reproductive cycles and lifespans. Additionally, genetically engineered mice can be utilized to investigate the relevance of specific genes, and their responses and changes to radiation [192,193]. In radiobiology, murine models are typically used to study the elaborated mechanisms of radiation-induced normal tissue and tumor response.

An important parameter affecting proton radiation-induced side effects is the RBE, which has been investigated in a number of in vivo experiments on mouse [41,47,193-197] and rat models [45,198-203] to estimate its values and dependence on other factors, such as LET, radiation dose and fractionation regime. The biological endpoint chosen for the RBE estimation highly depends on the tissue type. For spinal cord studies, myelopathies, such as paresis $[45,199,201]$ have been analyzed in rats, which develop radiation-induced symptoms similar to humans [204,205]. The intestine crypt survival assay [206] is a standardized method used in murine models to measure the gastrointestinal toxicity, a major dose-limiting factor during abdomen or pelvic irradiation. This approach is suitable to understand the differences between photon- and proton-induced intestinal injury [207] and is often used to compare proton facilities worldwide [193,208-212].

Another strength of in vivo models is reverse translation, i.e., replicating clinical observations in a preclinical setting. For example, recent studies have established proton irradiation of mouse brain subvolumes $[42,59]$ to investigate the underlying causes of radiation-induced brain lesions appearing after proton therapy $[10,18]$. Overall, central nervous system (CNS) toxicity studies in rodent models are of increasing interest and performed from both a behavioral [213-215] and histological perspective [59,216,217]. Using clinically relevant settings is crucial in developing protocols that reduce normal tissue complications. Amongst others, this includes the development of proton minibeam therapy $[28,29]$ and proton FLASH irradiation $[50,57,218,219]$. Further studies on normal tissue toxicities have focused on processes, such as the peripheral inflammatory response [220], radiation-induced thoracic injuries $[19,221]$, radiation-induced abdominal injury [207,222], as well as tumor incidence after irradiation of a healthy brain [223] and dorsal skin [224].

While sparing damage to the normal tissue is a critical aspect of RT, its primary goal is successful tumor eradication. Evaluation of radiotherapy treatments is often performed in rodent tumor models, using assays such as the TCD50 and tumor growth delay [153]. Orthotopic tumors are more clinically relevant, as the tumor is injected at the site of origin, but they also call for more complex irradiation protocols than subcutaneous ones. One example from the field of proton radiobiology is the study from Kwon et al. [225], which investigated the effect of proton therapy on tumor invasion and metastasis in the murine 
4T1 breast tumor model. Orthotopic transplantation has also been applied for brain tumor studies in a number of syngeneic rat models, for example, to compare conventional and proton minibeam RT [226-228]. Allograft C6 brain tumor-bearing rats served as a model to evaluate the feasibility of gene therapy together with proton radiation as an innovative approach with the potential to enhance the outcome of radiotherapy [229]. The majority of orthotopic tumors are syngeneic or allograft tumors, making them also suitable for immunological studies. This is, however, accompanied by the disadvantage of using animal cell lines, and thus, findings have to be considered with caution before they are extrapolated to human cancer therapies.

The similarities between animal tumor models and patients are higher in xenograft models. These tumors are usually inoculated subcutaneously to overcome technical limitations that come with orthotopical transplantation [230] and irradiation. In addition, they better depict the underlying biology and response of human cancers to radiation alone or in combination with different drugs. Xenograft tumor models have been used to investigate the effectiveness of proton irradiation for head and neck squamous cell carcinoma [231] and triple-negative breast cancer [232], as well as proton irradiation with ultra-high dose rates [233]. While studies that evaluate combination therapies with proton irradiation are still scarce, the cell-derived xenograft model is valuable for this research question. For example, Waissi et al. [234] found that application of gemcitabine- and olaparib-based chemoradiotherapy in such models displays a higher effectiveness when using proton therapy. Another preclinical study deduced that the combination of proton beam therapy with targeted radionuclide therapy can produce a type-dependent additive or synergetic effect [235]. Meanwhile, data on radioimmunotherapy with protons are still missing, but mouse xenograft studies using other radiation modalities have shown promising results [236,237].

In contrast to the cell-derived xenograft model, PDX are considered a suitable model for personalized oncology. They appear to have a higher predictive power, in particular for individual clinical outcomes. PDX are used to study tumor characteristics, develop metabolic and imaging biomarkers, facilitate clinical trial design, as well as prioritize therapeutic targets on a patient-based level [238]. A drawback of the xenograft models is that the tumor microenvironment can still deviate strongly from clinically relevant settings, depending on the tumor entity [239]. Another disadvantage is the suppressed immune system of the mice, which is necessary to prevent graft-versus-host disease after xenotransplantation. One solution to this would be humanized mice [239], but currently the complexity of this model is hardly compatible with the limitations of proton research, especially regarding the cost-benefit ratio.

Naturally, murine models offer the possibility to investigate the in vivo therapeutic window of radiation, which is defined by both tumor and normal tissue reactions. This research is especially interesting for preclinical studies with proton FLASH irradiation, which promises normal tissue protection at unvarying tumor control rates. Indeed, two recent studies could prove this effect in C57BL/ 6 mice $[218,219]$. Moreover, this valuable preclinical research has already culminated in the first feasibility study of proton FLASH irradiation in patients [240].

A less frequently applied rodent model for evaluating radiation responses is the Syrian hamster (Mesocricetus auratus) [241], which has not yet been used in particle therapy studies. Nevertheless, it has a rising importance in infectious disease research, which drives the development of laboratory procedures for this species [242]. In addition, the emergence of immunodeficient hamsters for xenograft studies [243,244] may increase the model's relevance for cancer radiobiology in the future.

In conclusion, rodent models provide an important preclinical setting to test a variety of radiobiological questions on both tumor and normal tissues. While mice provide more methodological options, e.g., through gene manipulation, rats can be irradiated more precisely and show higher similarities to human radiation responses. 


\subsection{Rabbits}

In proton research, rabbits are less frequently used to study normal tissue toxicity $[245,246]$ and more so to investigate the cancerous tissue response to irradiation. The VX2 tumor model is an anaplastic squamous cell carcinoma induced in rabbits that became a standard tool $[247,248]$ in oncology to study a number of solid human cancers [249]. VX2 tumor-bearing rabbits have been used to investigate proton irradiation effects for a multitude of entities with superficial tumors in the rabbit ear [250,251], as well as deep-laying ones in the lung [252,253], uterus [254], and pelvis [255]. The VX2 model is especially preferred when replicating and studying radiation-induced lung injury, as it overcomes limitations of immune-compromised murine models pertaining imaging, host immunity, and pathological changes $[253,256]$. This is because the syngeneic VX2 rabbit lung tumor model is relatively large and has more similarities to humans in terms of airway anatomy, which highlights the value of this model in investigating lung disease pathophysiologies [257]. Nevertheless, the advantages of this model are accompanied by the drawback of VX2 tumor being a neoplasm of rabbit origin with a microRNA profile that has little commonality to human patient samples [258]. In addition, rabbits have larger space requirements and animal handling is more complex than for rodents. This has led to a decreased use of rabbits as a cancer research model in recent years.

\subsection{Higher Mammals}

Large mammals, such as pigs, dogs, cats, and primates, better resemble the human anatomy and physiology than small animal models. Due to their larger size, clinical diagnostic tools and treatment devices can be utilized in preclinical research, which is particularly interesting for some reverse-translated issues. The most relevant results should be expected from primate studies, due to the close similarities to humans on a genetic, anatomical, and behavioral level. Indeed, one of the first publications on proton radiotherapy mentions tests on young monkeys [259]. In the last century, proton irradiation of primates has mainly been conducted in the context of military or space research, where it provided valuable findings on normal tissue toxicities [260-262]. Today, only a few institutes use primates as a model for radiation side effects [263-266], and just a single recent study irradiated with protons in their experiments [267]. Overall, the primate model is unlikely to play a pivotal role in future proton radiobiology studies in most cancer research institutions, due to high costs, long follow-up times, considerable ethical concerns, and constant public scrutiny.

Pigs and dogs, two other large mammals, offer similar advantages to primates concerning organ sizes, the immune system, physiology, and even genetics. Accordingly, radiation responses were frequently investigated in these models, in particular to assess normal tissue side effects [268]. Proton radiation of pigs was so far only carried out in the context of space research [269], but the species has been successfully applied with other radiation modalities to study normal tissue side effects in brain $[69,270]$ and skin [271]. Dogs, on the other hand, were already deployed in the early days of proton therapy, starting with a feasibility study of this irradiation source with canine pituitary gland and mammary cancer irradiation [259]. In the following years, beagles were also used for dosimetric and histological investigations of proton eye irradiation [272,273]. Classical studies on canines have declined in the last years; nevertheless, they have been used in proton research in a different context: the pet model for cancer treatment. Preclinical studies with domesticated animals that developed cancer naturally, e.g., cats and dogs [271,274-276], have the benefit that these tumors frequently show histopathological similarities to human tumors [277]. Pets often reach a high age and, thus, are likely afflicted by other age-related diseases as well. Due to differences in diet, life-style, and a living environment resembling the ones of their owners, pets better represent a heterogeneous patient population. In addition, this type of preclinical research is favorably perceived by the public [277], as opposed to conventional animal studies, which are regularly associated with a social stigma. Several cancer treatments have been tested in companion animals with success $[271,275,278]$, proving the utility of the model. An example for the use of pets in preclinical proton 
research is the study of Mayer-Stankeová et al. [276], who tested the safety of proton spot scanning in canine tumors. However, the less homogeneous conditions in these settings have to be taken into account, i.e., a higher sample size is required for statistically sound analyses. Additional challenges of the pet model are unclear ethical guidelines, extended experimental time frames, and a lower prevalence of certain tumor entities [279].

In summary, large mammals offer various benefits, compared to other preclinical models from a translational perspective. Nonetheless, they are also associated with several limitations, such as high costs, low throughput, ethical concerns, and high experimental complexity-not unlike clinical studies, but with lower clinical relevance. Therefore, the pros and cons of performing a study on higher mammals instead of a clinical trial have to be carefully balanced, according to the research question at hand. Even then, implementing experiments with large animals may often not be technically feasible at existing beam lines due to missing infrastructures. Nevertheless, the option for irradiating large animals needs to be considered when designing and building new proton facilities with research units.

\section{In Silico Models}

In this chapter, a concise summary of the manifold in silico models, which are used to describe, understand and support proton radiobiology, is given. The list might not be exhaustive, but contains models on different dimensions and complexities, as briefly summarized in Figure 4.

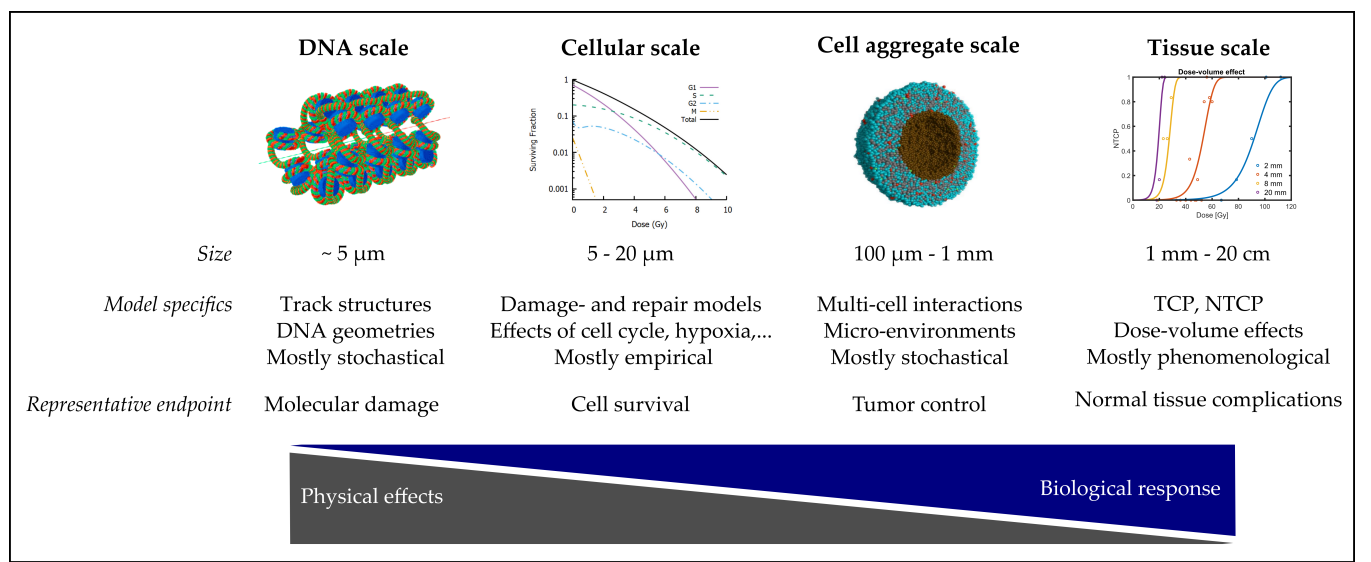

Figure 4. Overview of in silico models for proton radiobiology experiments. Images (left to right): chromatin fiber [280], surviving cell fraction in dependence on the cell cycle phase [281], simulated tumor spheroid $40 \mathrm{~min}$ post photon irradiation [70], NTCP model for increasing irradiation volumes (courtesy of E.Ba.).

Computational models are crucial tools in proton radiobiological research due to the inherently quantitative nature of biological dose responses to radiation. While analytical mathematical models have been used in radiobiology since the beginning, today, stochastic numerical methods are employed more and more frequently. Due to the high complexity of the studied biological systems, a purely mechanistic description is still not achievable. Most models are therefore purely phenomenological or semi-mechanistic. Between the different scales of interest from molecules to entire organs, models vary substantially in methodology, complexity and predictive power. An extensive review on radiation response models can also be found in [282].

\subsection{From Particle Tracks to DNA Damage}

A substantial portion of radiobiological research is concerned with the question how biological damage is quantitatively related to radiation characteristics. Radiation damage to cells has been shown experimentally to correlate with the amount of double-strand breaks. This amount depends not only on the (macroscopically averaged quantity) dose, but more precisely on the distributions of energy deposition events at molecular scales, 
as described by track structures. These are commonly modeled stochastically, for which a large number of Monte Carlo (MC) particle transport codes exists [280,283-288]. The different codes are discussed in detail in [289]. Since the required computational efforts limit these calculations to microscopic scales, MC codes apply approximative calculations for macroscopic simulations of dose and LET distributions, using the condensed history approach [290,291].

The calculated microscopic distributions of energy deposition events can then be used to model distributions of DNA damage. Here, the diffusion and reaction of chemical radicals also play important roles regarding indirect damage, which requires additional modeling [292]. In a next step, DNA repair mechanisms are often simulated with systems of differential equations [293-295] or MC approaches [296-299]. Such modeling approaches allow gaining insights into, for example, the effect of chromatin geometry [300,301], or the relation between LET and radiation modality [302-304] on the RBE of different DNA damage endpoints.

\subsection{Cellular Scale}

The relation between radiation and cell response is highly complex and depends on various signaling cascades. In response to radiation-induced DNA damage, cells can undergo a variety of responses, such as cell cycle arrest, apoptosis, or mitotic death. In vitro, the cell-level dose-response is commonly assayed by scoring cell survival, i.e., the proportion of colony-forming cells, using the clonogenic survival assay. The observation that cell survival does not decrease exponentially with dose, but forms a "shoulder", has led to a multitude of models attempting to provide mechanistic descriptions of the observed behavior. Since the 1980s, the phenomenological linear-quadratic (LQ) model (reviewed in [281]) has been well established for all practical purposes, where the logarithm of cell survival as a function of dose is described by a second-order polynomial fit. Early mechanistic models attempted to explain the observed behavior by assuming that lethal lesions to a cell (such as asymmetric exchange-type aberrations) may occur either directly or indirectly via some second-order rate process, such as the interaction of two DNA double-strand breaks $[305,306]$. Later models assumed that lesions may or may not develop into lethal lesions, depending on the success and kinetics of DNA repair processes [307-309]. A generally accepted explanation is still lacking (reviewed in [282,310]). Of note, all mentioned models rely on experimental cell survival data as scored in the clonogenic survival assay. Recently, the validity of the assaying procedure was called into question after time-lapse imaging revealed a large heterogeneity of colony growth rates after irradiation [311].

Many computational RBE models (summarized in [312]) are similarly constructed as the above-mentioned models, with the difference that the occurrence of lethal and sublethal lesions depends, besides dose, on additional parameters describing beam physics (commonly LET). The semi-mechanistic local effect model and the microdosimetric kinetic model employ track-structure assumptions and are particularly used for carbon ion radiation $[313,314]$. For proton radiation, several established phenomenological models share a similar structure, where the LQ parameters are modeled as functions of LET [315-317]. The predictive power of these models is hampered by the fact that the underlying experimental data exhibit a large variability [14].

\subsection{Cell Aggregate Scale}

Spheroids, organoids and tumor masses are often modeled stochastically, using methods such as cellular automata, the Potts model or agent-based models, made up of individual cells as base units [318]. The effect of radiation on tumor masses has also been modeled stochastically by numerous models, frequently with a special focus on the effects of tumor vascularization and oxygenation (reviewed in [319]).

The intestinal crypt survival assay is an established endpoint that allows to study dose response on a cell level in vivo [206] and yields important data for the RBE of protons [14]. It is commonly modeled by simplified analytical formulas [206], which have 
been used extensively for generating biological hypotheses in radiobiological and stem cell research [320,321]. Novel stochastic modeling approaches of the biological processes as well as the assay procedure yield, for example, mechanistic insights into the dose-volume effect [322,323].

\subsection{Tissue Scale}

The goal of most radiobiological research is quantifying the effect of radiation on organs and tumors to improve the outcome in clinical applications. Yet, the mechanisms of these effects are poorly understood, and tissue-scale models are largely phenomenological. Tumor control is assumed to be achieved when all clonogenic tumor cells have been depleted by radiation, which forms the basis of most TCP models [324]. However, this paradigm has been increasingly challenged by new biological insights [325]. In normal tissues, the dose response differs largely from what would be expected from simple cell killing. The most important differences lie in the dose-volume effects, i.e., complex relations between spatial distributions of dose and outcome [199,326,327] and in the occurrence of late radiation effects with unexplained long latencies and complex doselatency relations [326,328,329]. Normal tissue complication probability (NTCP) models aim to capture dose-volume effects, employing either empirical scaling laws [330,331], or dividing the tissue into hypothetical sub-units, which give rise to the concepts of serial and parallel organization [332-334]. Novel modeling approaches employ methods from statistical physics [335].

Since these observations are similar in both preclinical and clinical data, there is great interest in translational modeling [336] and several models are routinely used in clinical practice. In treatment planning, dose-volume effects are incorporated in the form of constraints and objectives of optimization algorithms (e.g., equivalent uniform dose and dose-volume histogram parameters). In carbon ion therapy, a model-based RBE is used for treatment planning [337,338]. In the Netherlands, NTCP model-based patient selection is being used to decide between photon and proton therapy [339]. For clinical data analysis, voxel-level modeling is increasingly employed to resolve the spatial information of complications, especially with regard to the RBE of proton radiation $[8,10,340-342]$.

\section{Conclusions}

In line with the increasing number of proton facilities, proton RT has become part of the standard care for certain tumor types. However, despite the growing number of treated patients, further research is still needed to improve therapy and answer numerous open questions, e.g., those on potential differences in proton and photon radiobiology or alterations in chemoradiotherapy effects. In addition, new trends emerging in clinical oncology would benefit from preclinical research. For example, one recent treatment approach with great potential is combined immuno-radiotherapy, but unfortunately, no data with proton radiation are available so far; thus, translational efforts to combinatorial proton therapy are highly in need. Some of these points might be answered in clinical trials, which can nowadays be organized as multicentric studies, due to the increasing number of proton centers worldwide. Nevertheless, specific mechanistic or radiobiological aspects should be investigated in translational research studies (Figure 1) under careful consideration of models and endpoints. Starting from in silico approaches to large animals, each model described in this review has specific characteristics that might favor it over the others, depending on the research question at hand (Table 1). Mechanistic studies are most frequently performed in in vitro systems since cell cultures are easy to manipulate and different treatment modalities can be systematically tested in a short time. Other topics, such as tissue responses to radiation, demand for animal models, which need to be chosen, according to the available proton beam parameters and experimental equipment at each proton site. 
Table 1. Literature overview of preclinical models for investigations of proton-specific research questions.

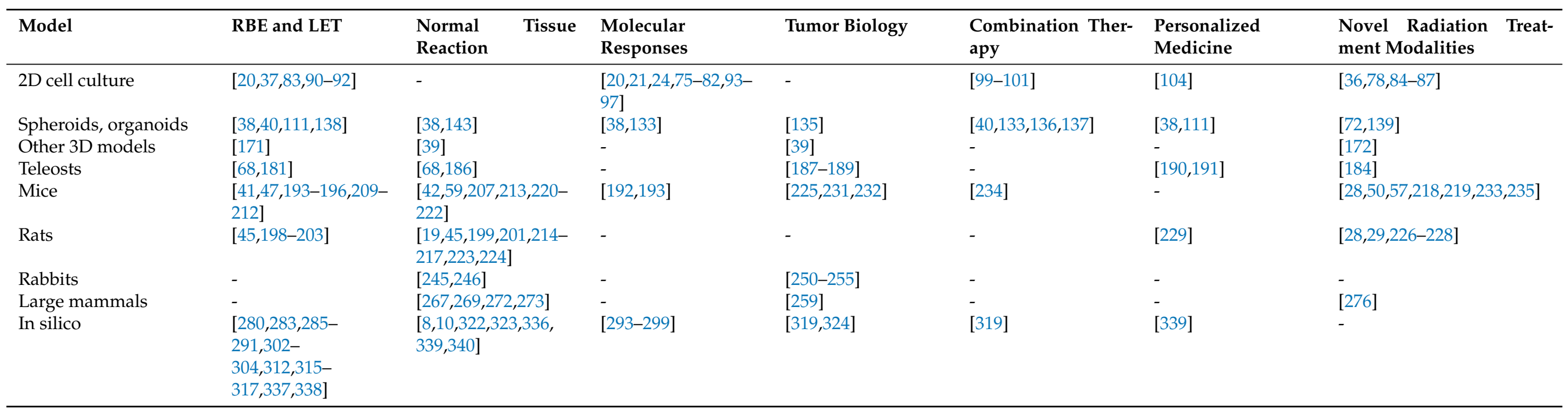


Although the models highlighted in the present overview follow the standard translational research chain, it is worth noting that this chain is not a one-way street. Preclinical studies are often performed in forward translation to answer basic questions, for example, on the LET dependence of the proton RBE, translating the obtained results into clinical trials. However, clinical problems can also be back-translated to the laboratory to gain insight into the underlying mechanisms that cannot be studied in patients. Both forward and reverse translation in proton RT research are at the intersection of medicine, radiobiology and physics. Therefore, translational proton research requires interdisciplinary efforts, where physicists, biologists and clinicians share knowledge and skills to answer complex radiobiological scenarios with adequate preclinical models.

Author Contributions: All authors contributed to the conceptualization, investigation, data curation (i.e., Table 1), writing and reviewing of the original draft. T.S., A.D., R.K., E.B. (Emanuel Bahn) and E.B. (Elke Beyreuther) performed visualization. All authors have read and agreed to the published version of the manuscript.

Funding: R.K. and E.B. (Emanuel Bahn) were supported by the Alois Hirdt-Erben und WielandStiftung.

Acknowledgments: We thank Max Naumann for contributing an image of organoids and Thomas E. Schmid for scientific discussion. Furthermore, we want to acknowledge the creators of Excel2LaTeX (https:/ / github.com/krlmlr/Excel2LaTeX accessed on 15 June 2021).

Conflicts of Interest: The authors declare no conflict of interest.

\section{References}

1. Verma, V.; Simone, C.B.; Mishra, M.V. Quality of life and patient-reported outcomes following proton radiation therapy: A systematic review. JNCI J. Natl. Cancer Inst. 2018, 110, 341-353. [CrossRef]

2. Ramaekers, B.L.; Pijls-Johannesma, M.; Joore, M.A.; Van Den Ende, P.; Langendijk, J.A.; Lambin, P.; Kessels, A.G.; Grutters, J.P. Systematic review and meta-analysis of radiotherapy in various head and neck cancers: Comparing photons, carbon-ions and protons. Cancer Treat. Rev. 2011, 37, 185-201. [CrossRef] [PubMed]

3. Paganetti, H.; Athar, B.S.; Moteabbed, M.; Adams, J.A.; Schneider, U.; Yock, T.I. Assessment of radiation-induced second cancer risks in proton therapy and IMRT for organs inside the primary radiation field. Phys. Med. Biol. 2012, 57, 6047. [CrossRef]

4. Sato, H.; Mizumoto, M.; Okumura, T.; Sakurai, H.; Sakamoto, N.; Akutsu, H.; Ishikawa, E.; Tsuboi, K. Long-term outcomes of patients with unresectable benign meningioma treated with proton beam therapy. J. Radiat. Res. 2021, 62, 427-437. [CrossRef] [PubMed]

5. PTCOG. 2021. Available online: https://www.ptcog.ch/ (accessed on 14 April 2021).

6. Paganetti, H.; Blakely, E.; Carabe-Fernandez, A.; Carlson, D.J.; Das, I.J.; Dong, L.; Grosshans, D.; Held, K.D.; Mohan, R.; Moiseenko, V.; et al. Report of the AAPM TG-256 on the relative biological effectiveness of proton beams in radiation therapy. Med. Phys. 2019, 46, e53-e78. [CrossRef]

7. Peeler, C.R.; Mirkovic, D.; Titt, U.; Blanchard, P.; Gunther, J.R.; Mahajan, A.; Mohan, R.; Grosshans, D.R. Clinical evidence of variable proton biological effectiveness in pediatric patients treated for ependymoma. Radiother. Oncol. 2016, 121, 395-401. [CrossRef] [PubMed]

8. Eulitz, J.; Lutz, B.; Wohlfahrt, P.; Dutz, A.; Enghardt, W.; Karpowitz, C.; Krause, M.; Troost, E.; Lühr, A. A Monte Carlo based radiation response modelling framework to assess variability of clinical RBE in proton therapy. Phys. Med. Biol. 2019, 64, 225020. [CrossRef]

9. Underwood, T.S.; Grassberger, C.; Bass, R.; MacDonald, S.M.; Meyersohn, N.M.; Yeap, B.Y.; Jimenez, R.B.; Paganetti, H. Asymptomatic late-phase radiographic changes among chest-wall patients are associated with a proton RBE exceeding 1.1. Int. J. Radiat. Oncol. Biol. Phys. 2018, 101, 809-819. [CrossRef] [PubMed]

10. Bahn, E.; Bauer, J.; Harrabi, S.; Herfarth, K.; Debus, J.; Alber, M. Late contrast enhancing brain lesions in proton-treated patients with low-grade glioma: Clinical evidence for increased periventricular sensitivity and variable RBE. Int. J. Radiat. Oncol. Biol. Phys. 2020, 107, 571-578. [CrossRef] [PubMed]

11. Sánchez-Parcerisa, D.; López-Aguirre, M.; Dolcet Llerena, A.; Udías, J.M. MultiRBE: Treatment planning for protons with selective radiobiological effectiveness. Med. Phys. 2019, 46, 4276-4284. [CrossRef]

12. Tilly, N.; Johansson, J.; Isacsson, U.; Medin, J.; Blomquist, E.; Grusell, E.; Glimelius, B. The influence of RBE variations in a clinical proton treatment plan for a hypopharynx cancer. Phys. Med. Biol. 2005, 50, 2765. [CrossRef]

13. Lühr, A.; von Neubeck, C.; Krause, M.; Troost, E.G. Relative biological effectiveness in proton beam therapy-Current knowledge and future challenges. Clin. Transl. Radiat. Oncol. 2018, 9, 35-41. [CrossRef]

14. Paganetti, H. Relative biological effectiveness (RBE) values for proton beam therapy. Variations as a function of biological endpoint, dose, and linear energy transfer. Phys. Med. Biol. 2014, 59, R419. [CrossRef] 
15. Ilicic, K.; Combs, S.; Schmid, T. New insights in the relative radiobiological effectiveness of proton irradiation. Radiat. Oncol. 2018, 13, 1-8. [CrossRef]

16. Sørensen, B.S. Commentary: RBE in proton therapy-where is the experimental in vivo data? Acta Oncol. 2019, 58, 1337-1339. [CrossRef]

17. Baumann, M.; Krause, M.; Overgaard, J.; Debus, J.; Bentzen, S.M.; Daartz, J.; Richter, C.; Zips, D.; Bortfeld, T. Radiation oncology in the era of precision medicine. Nat. Rev. Cancer 2016, 16, 234. [CrossRef]

18. Eulitz, J.; Troost, E.; Raschke, F.; Schulz, E.; Lutz, B.; Dutz, A.; Löck, S.; Wohlfahrt, P.; Enghardt, W.; Karpowitz, C.; et al. Predicting late magnetic resonance image changes in glioma patients after proton therapy. Acta Oncol. 2019, 58, 1536-1539. [CrossRef]

19. Coppes, R.P.; Muijs, C.T.; Faber, H.; Gross, S.; Schippers, J.M.; Brandenburg, S.; Langendijk, J.A.; van Luijk, P. Volume-dependent expression of in-field and out-of-field effects in the proton-irradiated rat lung. Int. J. Radiat. Oncol. Biol. Phys. 2011, 81, 262-269. [CrossRef]

20. Oeck, S.; Szymonowicz, K.; Wiel, G.; Krysztofiak, A.; Lambert, J.; Koska, B.; Iliakis, G.; Timmermann, B.; Jendrossek, V. Relating linear energy transfer to the formation and resolution of DNA repair foci after irradiation with equal doses of X-ray photons, plateau, or Bragg-peak protons. Int. J. Mol. Sci. 2018, 19, 3779. [CrossRef]

21. Zaboronok, A.; Isobe, T.; Yamamoto, T.; Sato, E.; Takada, K.; Sakae, T.; Tsurushima, H.; Matsumura, A. Proton beam irradiation stimulates migration and invasion of human U87 malignant glioma cells. J. Radiat. Res. 2014, 55, 283-287. [CrossRef]

22. Jasińska-Konior, K.; Pochylczuk, K.; Czajka, E.; Michalik, M.; Romanowska-Dixon, B.; Swakoń, J.; Urbańska, K.; Elas, M. Proton beam irradiation inhibits the migration of melanoma cells. PLoS ONE 2017, 12, e0186002. [CrossRef]

23. Girdhani, S.; Sachs, R.; Hlatky, L. Biological Effects of Proton Radiation: What We Know and Don't Know. Radiat. Res. 2013, 179, 257-272. [CrossRef]

24. Ogata, T.; Teshima, T.; Kagawa, K.; Hishikawa, Y.; Takahashi, Y.; Kawaguchi, A.; Suzumoto, Y.; Nojima, K.; Furusawa, Y.; Matsuura, N. Particle irradiation suppresses metastatic potential of cancer cells. Cancer Res. 2005, 65, 113-120.

25. Lee, H.J., Jr.; Zeng, J.; Rengan, R. Proton beam therapy and immunotherapy: An emerging partnership for immune activation in non-small cell lung cancer. Transl. Lung Cancer Res. 2018, 7, 180. [CrossRef]

26. Favaudon, V.; Caplier, L.; Monceau, V.; Pouzoulet, F.; Sayarath, M.; Fouillade, C.; Poupon, M.F.; Brito, I.; Hupé, P.; Bourhis, J.; et al. Ultrahigh dose-rate FLASH irradiation increases the differential response between normal and tumor tissue in mice. Sci. Transl. Med. 2014, 6, 245ra93. [CrossRef]

27. Wilson, J.D.; Hammond, E.M.; Higgins, G.S.; Petersson, K. Ultra-high dose rate (FLASH) radiotherapy: Silver bullet or fool's gold? Front. Oncol. 2020, 9, 1563. [CrossRef] [PubMed]

28. Girst, S.; Greubel, C.; Reindl, J.; Siebenwirth, C.; Zlobinskaya, O.; Walsh, D.W.; Ilicic, K.; Aichler, M.; Walch, A.; Wilkens, J.J.; et al. Proton minibeam radiation therapy reduces side effects in an in vivo mouse ear model. Int. J. Radiat. Oncol. Biol. Phys. 2016, 95, 234-241. [CrossRef] [PubMed]

29. Prezado, Y.; Jouvion, G.; Hardy, D.; Patriarca, A.; Nauraye, C.; Bergs, J.; González, W.; Guardiola, C.; Juchaux, M.; Labiod, D.; et al. Proton minibeam radiation therapy spares normal rat brain: Long-Term Clinical, Radiological and Histopathological Analysis. Sci. Rep. 2017, 7, 1-7. [CrossRef]

30. Beyreuther, E.; Baumann, M.; Enghardt, W.; Helmbrecht, S.; Karsch, L.; Krause, M.; Pawelke, J.; Schreiner, L.; Schürer, M.; von Neubeck, C.; et al. Research Facility for Radiobiological Studies at the University Proton Therapy Dresden. Int. J. Part. Ther. 2018, 5, 172-182. [CrossRef] [PubMed]

31. Patriarca, A.; Fouillade, C.; Auger, M.; Martin, F.; Pouzoulet, F.; Nauraye, C.; Heinrich, S.; Favaudon, V.; Meyroneinc, S.; Dendale, R.; et al. Experimental set-up for FLASH proton irradiation of small animals using a clinical system. Int. J. Radiat. Oncol. Biol. Phys. 2018, 102, 619-626. [CrossRef] [PubMed]

32. Henthorn, N.T.; Sokol, O.; Durante, M.; De Marzi, L.; Pouzoulet, F.; Miszczyk, J.; Olko, P.; Brandenburg, S.; van Goethem, M.J.; Barazzuol, L.; et al. Mapping the Future of Particle Radiobiology in Europe: The INSPIRE Project. Front. Phys. 2020, 8, 438. [CrossRef]

33. Andreo, P.; Burns, D.T.; Hohlfeld, K.; Huq, M.S.; Kanai, T.; Laitano, F.; Smyth, V.; Vynckier, S. Absorbed Dose Determination in External Beam Radiotherapy: An International Code of Practice for Dosimetry Based on Standards of Absorbed Dose to Water; International Atomic Energy Agency: Vienna, Austria, 2000; Volume 11.

34. Anderson, S.E.; Grams, M.P.; Tseung, H.W.C.; Furutani, K.M.; Beltran, C.J. A linear relationship for the LET-dependence of Gafchromic EBT3 film in spot-scanning proton therapy. Phys. Med. Biol. 2019, 64, 055015. [CrossRef] [PubMed]

35. Beni, M.S.; Krstic, D.; Nikezic, D.; Yu, K.N. Medium-thickness-dependent proton dosimetry for radiobiological experiments. Sci. Rep. 2019, 9, 1-7.

36. Marshall, T.I.; Chaudhary, P.; Michaelidesová, A.; Vachelová, J.; Davídková, M.; Vondráček, V.; Schettino, G.; Prise, K.M. Investigating the Implications of a Variable RBE on Proton Dose Fractionation Across a Clinical Pencil Beam Scanned Spread-Out Bragg Peak. Int. J. Radiat. Oncol. Biol. Phys. 2016. [CrossRef]

37. Guan, F.; Bronk, L.; Titt, U.; Lin, S.H.; Mirkovic, D.; Kerr, M.D.; Zhu, X.R.; Dinh, J.; Sobieski, M.; Stephan, C.; et al. Spatial mapping of the biologic effectiveness of scanned particle beams: Towards biologically optimized particle therapy. Sci. Rep. 2015, 5,1-10. [CrossRef] 
38. Nowrouzi, A.; Sertorio, M.G.; Akbarpour, M.; Knoll, M.; Krunic, D.; Kuhar, M.; Schwager, C.; Brons, S.; Debus, J.; Wells, S.I.; et al. Personalized Assessment of Normal Tissue Radiosensitivity via Transcriptome Response to Photon, Proton and Carbon Irradiation in Patient-Derived Human Intestinal Organoids. Cancers 2020, 12, 469. [CrossRef] [PubMed]

39. Suckert, T.; Rassamegevanon, T.; Müller, J.; Dietrich, A.; Graja, A.; Reiche, M.; Löck, S.; Krause, M.; Beyreuther, E.; von Neubeck, C. Applying Tissue Slice Culture in Cancer Research-Insights from Preclinical Proton Radiotherapy. Cancers 2020, $12,1589$. [CrossRef]

40. Görte, J.; Beyreuther, E.; Danen, E.H.; Cordes, N. Comparative Proton and Photon Irradiation Combined with Pharmacological Inhibitors in 3D Pancreatic Cancer Cultures. Cancers 2020, 12, 3216. [CrossRef]

41. Tepper, J.; Verhey, L.; Goitein, M.; Suit, H.D.; Phil, D.; Koehler, A.M. In vivo determinations of RBE in a high energy modulated proton beam using normal tissue reactions and fractionated dose schedules. Int. J. Radiat. Oncol. Biol. Phys. 1977, 2, 1115-1122. [CrossRef]

42. Suckert, T.; Müller, J.; Beyreuther, E.; Azadegan, B.; Brüggemann, A.; Bütof, R.; Dietrich, A.; Gotz, M.; Haase, R.; Schürer, M.; et al. High-precision image-guided proton irradiation of mouse brain sub-volumes. Radiother. Oncol. 2020, 146, 205-212. [CrossRef]

43. Van Luijk, P.; Pringle, S.; Deasy, J.O.; Moiseenko, V.V.; Faber, H.; Hovan, A.; Baanstra, M.; van der Laan, H.P.; Kierkels, R.G.; van der Schaaf, A.; et al. Sparing the region of the salivary gland containing stem cells preserves saliva production after radiotherapy for head and neck cancer. Sci. Transl. Med. 2015, 7, 305ra147. [CrossRef]

44. Howard, M.E.; Denbeigh, J.M.; Debrot, E.K.; Garcia, D.A.; Remmes, N.B.; Herman, M.G.; Beltran, C.J. Dosimetric Assessment of a High Precision System for Mouse Proton Irradiation to Assess Spinal Cord Toxicity. Radiat. Res. 2021, 195, 541-548. [CrossRef]

45. Saager, M.; Peschke, P.; Brons, S.; Debus, J.; Karger, C.P. Determination of the proton RBE in the rat spinal cord: Is there an increase towards the end of the spread-out Bragg peak? Radiother. Oncol. 2018. [CrossRef]

46. Gerlach, S.; Pinto, M.; Kurichiyanil, N.; Grau, C.; Herault, J.; Hillbrand, M.; Poulsen, P.; Safai, S.; Schippers, J.M.; Schwarz, M.; et al. Beam characterization and feasibility study for a small animal irradiation platform at clinical proton therapy facilities. Phys. Med. Biol. 2020, 65, 245045. [CrossRef] [PubMed]

47. Sørensen, B.S.; Bassler, N.; Nielsen, S.; Horsman, M.R.; Grzanka, L.; Spejlborg, H.; Swakoń, J.; Olko, P.; Overgaard, J. Relative biological effectiveness (RBE) and distal edge effects of proton radiation on early damage in vivo. Acta Oncol. 2017. [CrossRef]

48. Besuglow, J.; Echner, G.; Mairani, A.; Alber, M.; Bahn, E. EP-1938 A high precision irradiation system for in vivo RBE measurements with ion beams. Radiother. Oncol. 2019, 133, S1055-S1056. [CrossRef]

49. Kim, M.M.; Irmen, P.; Shoniyozov, K.; Verginadis, I.I.; Cengel, K.A.; Koumenis, C.; Metz, J.M.; Dong, L.; Diffenderfer, E.S. Design and commissioning of an image-guided small animal radiation platform and quality assurance protocol for integrated proton and x-ray radiobiology research. Phys. Med. Biol. 2019, 64, 135013. [CrossRef]

50. Zhang, Q.; Cascio, E.; Li, C.; Yang, Q.; Gerweck, L.E.; Huang, P.; Gottschalk, B.; Flanz, J.; Schuemann, J. Flash investigations using protons: Design of delivery system, preclinical setup and confirmation of flash effect with protons in animal systems. Radiat. Res. 2020, 194, 656-664. [CrossRef] [PubMed]

51. Jorge, P.G.; Jaccard, M.; Petersson, K.; Gondré, M.; Durán, M.T.; Desorgher, L.; Germond, J.F.; Liger, P.; Vozenin, M.C.; Bourhis, J.; et al. Dosimetric and preparation procedures for irradiating biological models with pulsed electron beam at ultra-high dose-rate. Radiother. Oncol. 2019, 139, 34-39. [CrossRef]

52. Karsch, L.; Beyreuther, E.; Burris-Mog, T.; Kraft, S.; Richter, C.; Zeil, K.; Pawelke, J. Dose rate dependence for different dosimeters and detectors: TLD, OSL, EBT films, and diamond detectors. Med. Phys. 2012, 39, 2447-2455. [CrossRef]

53. Patallo, I.S.; Subiel, A.; Westhorpe, A.; Gouldstone, C.; Tulk, A.; Sharma, R.A.; Schettino, G. Development and Implementation of an End-To-End Test for Absolute Dose Verification of Small Animal Preclinical Irradiation Research Platforms. Int. J. Radiat. Oncol. Biol. Phys. 2020, 107, 587-596. [CrossRef] [PubMed]

54. Esplen, N.; Mendonca, M.S.; Bazalova-Carter, M. Physics and biology of ultrahigh dose-rate (FLASH) radiotherapy: A topical review. Phys. Med. Biol. 2020, 65, 23TR03. [CrossRef] [PubMed]

55. Mazal, A.; Vera Sanchez, J.A.; Sanchez-Parcerisa, D.; Udias, J.M.; España, S.; Sanchez-Tembleque, V.; Fraile, L.M.; Bragado, P.; Gutierrez-Uzquiza, A.; Gordillo, N.; et al. Biological and Mechanical Synergies to Deal with Proton Therapy Pitfalls: Minibeams, FLASH, Arcs, and Gantryless Rooms. Front. Oncol. 2021, 10, 3109. [CrossRef] [PubMed]

56. Chaudhary, P.; Milluzzo, G.; Ahmed, H.; Odlozilik, B.; McMurray, A.; Prise, K.; Borghesi, M. Radiobiology experiments with ultra-high dose rate laser-driven protons: Methodology and state-of-the-art. Front. Phys. 2021, 9, 624963. [CrossRef]

57. Kourkafas, G.; Bundesmann, J.; Fanselow, T.; Denker, A.; Ehrhardt, V.H.; Gollrad, J.; Budach, V.; Weber, A.; Kociok, N.; Joussen, A.M.; et al. FLASH proton irradiation setup with a modulator wheel for a single mouse eye. Med. Phys. 2021, 48, 1839-1845. [CrossRef]

58. Perl, J.; Shin, J.; Schümann, J.; Faddegon, B.; Paganetti, H. TOPAS: An innovative proton Monte Carlo platform for research and clinical applications. Med. Phys. 2012, 39, 6818-6837. [CrossRef]

59. Suckert, T.; Beyreuther, E.; Müller, J.; Azadegan, B.; Meinhardt, M.; Raschke, F.; Bodenstein, E.; von Neubeck, C.; Lühr, A.; Krause, M.; et al. Late Side Effects in Normal Mouse Brain Tissue After Proton Irradiation. Front. Oncol. 2021, 10, 1-17. [CrossRef]

60. Guardiola, C.; De Marzi, L.; Prezado, Y. Verification of a Monte Carlo dose calculation engine in proton minibeam radiotherapy in a passive scattering beamline for preclinical trials. Br. J. Radiol. 2020, 93, 20190578. [CrossRef] 
61. Price, G.; Biglin, E.R.; Collins, S.; Aitkinhead, A.; Subiel, A.; Chadwick, A.L.; David, M.C.; Kirkby, K.J.; Schettino, G.; Tipping, J.; et al. An open source heterogeneous 3D printed mouse phantom utilising a novel bone representative thermoplastic. Phys. Med. Biol. 2020, 65, 10NT02. [CrossRef]

62. Desrosiers, M.; DeWerd, L.; Deye, J.; Lindsay, P.; Murphy, M.K.; Mitch, M.; Macchiarini, F.; Stojadinovic, S.; Stone, H. The importance of dosimetry standardization in radiobiology. J. Res. Natl. Inst. Stand. Technol. 2013, 118, 403. [CrossRef] [PubMed]

63. Draeger, E.; Sawant, A.; Johnstone, C.; Koger, B.; Becker, S.; Vujaskovic, Z.; Jackson, I.L.; Poirier, Y. A dose of reality: How 20 years of incomplete physics and dosimetry reporting in radiobiology studies may have contributed to the reproducibility crisis. Int. J. Radiat. Oncol. Biol. Phys. 2020, 106, 243-252. [CrossRef] [PubMed]

64. Krause, M.; Alsner, J.; Linge, A.; Bütof, R.; Löck, S.; Bristow, R. Specific requirements for translation of biological research into clinical radiation oncology. Mol. Oncol. 2020, 14, 1569-1576. [CrossRef] [PubMed]

65. Verhaegen, F.; Dubois, L.; Gianolini, S.; Hill, M.A.; Karger, C.P.; Lauber, K.; Prise, K.M.; Sarrut, D.; Thorwarth, D.; Vanhove, C.; et al. ESTRO ACROP: Technology for precision small animal radiotherapy research: Optimal use and challenges. Radiother. Oncol. 2018, 126, 471-478. [CrossRef]

66. Baker, M. Reproducibility crisis. Nature 2016, 533, 353-366.

67. Hutchinson, L.; Kirk, R. High drug attrition rates-where are we going wrong? Nat. Rev. Clin. Oncol. 2011, 8, 189-190. [CrossRef]

68. Szabó, E.R.; Brand, M.; Hans, S.; Hideghéty, K.; Karsch, L.; Lessmann, E.; Pawelke, J.; Schürer, M.; Beyreuther, E. Radiobiological effects and proton RBE determined by wildtype zebrafish embryos. PLoS ONE 2018, 13, e0206879. [CrossRef] [PubMed]

69. Athanasiadi, I.; Perez, W.D.; Plantenga, J.M.; Jones-Hall, Y.; Perez-Torres, C.J. Feasibility of a mini-pig model of radiation-induced brain injury to one cerebral hemisphere. Radiat. Oncol. 2021, 16, 1-8. [CrossRef]

70. Kempf, H.; Hatzikirou, H.; Bleicher, M.; Meyer-Hermann, M. In silico analysis of cell cycle synchronisation effects in radiotherapy of tumour spheroids. PLoS Comput. Biol. 2013, 9, e1003295. [CrossRef]

71. Auer, S.; Hable, V.; Greubel, C.; Drexler, G.A.; Schmid, T.E.; Belka, C.; Dollinger, G.; Friedl, A.A. Survival of tumor cells after proton irradiation with ultra-high dose rates. Radiat. Oncol. 2011, 6, 1-8. [CrossRef]

72. Brack, F.E.; Kroll, F.; Gaus, L.; Bernert, C.; Beyreuther, E.; Cowan, T.E.; Karsch, L.; Kraft, S.; Kunz-Schughart, L.A.; Lessmann, E.; et al. Spectral and spatial shaping of laser-driven proton beams using a pulsed high-field magnet beamline. Sci. Rep. 2020, $10,1-12$.

73. Kapałczyńska, M.; Kolenda, T.; Przybyła, W.; Zajączkowska, M.; Teresiak, A.; Filas, V.; Ibbs, M.; Bliźniak, R.; Łuczewski, Ł.; Lamperska, K. 2D and 3D cell cultures-a comparison of different types of cancer cell cultures. Arch. Med. Sci. AMS 2018, 14, 910.

74. Kaur, G.; Dufour, J.M. Cell lines: Valuable tools or useless artifacts. Spermatogenesis 2012, 2, 1-5. [CrossRef] [PubMed]

75. Mitteer, R.A.; Wang, Y.; Shah, J.; Gordon, S.; Fager, M.; Butter, P.P.; Kim, H.J.; Guardiola-Salmeron, C.; Carabe-Fernandez, A.; Fan, Y. Proton beam radiation induces DNA damage and cell apoptosis in glioma stem cells through reactive oxygen species. Sci. Rep. 2015, 5, 1-12.

76. Lee, K.B.; Lee, J.S.; Park, J.W.; Huh, T.L.; Lee, Y.M. Low energy proton beam induces tumor cell apoptosis through reactive oxygen species and activation of caspases. Exp. Mol. Med. 2008, 40, 118-129. [CrossRef] [PubMed]

77. Schmid, T.; Dollinger, G.; Hauptner, A.; Hable, V.; Greubel, C.; Auer, S.; Friedl, A.; Molls, M.; Röper, B. No evidence for a different RBE between pulsed and continuous $20 \mathrm{MeV}$ protons. Radiat. Res. 2009, 172, 567-574. [CrossRef] [PubMed]

78. Buonanno, M.; Grilj, V.; Brenner, D.J. Biological effects in normal cells exposed to FLASH dose rate protons. Radiother. Oncol. 2019, 139, 51-55. [CrossRef] [PubMed]

79. Zlobinskaya, O.; Dollinger, G.; Michalski, D.; Hable, V.; Greubel, C.; Du, G.; Multhoff, G.; Röper, B.; Molls, M.; Schmid, T. Induction and repair of DNA double-strand breaks assessed by gamma-H2AX foci after irradiation with pulsed or continuous proton beams. Radiat. Environ. Biophys. 2012, 51, 23-32. [CrossRef]

80. Fontana, A.O.; Augsburger, M.A.; Grosse, N.; Guckenberger, M.; Lomax, A.J.; Sartori, A.A.; Pruschy, M.N. Differential DNA repair pathway choice in cancer cells after proton-and photon-irradiation. Radiother. Oncol. 2015, 116, 374-380. [CrossRef]

81. Narang, H.; Kumar, A.; Bhat, N.; Pandey, B.N.; Ghosh, A. Effect of proton and gamma irradiation on human lung carcinoma cells: Gene expression, cell cycle, cell death, epithelial-mesenchymal transition and cancer-stem cell trait as biological end points Mutat. Res. Mol. Mech. Mutagen. 2015, 780, 35-46. [CrossRef]

82. Cuaron, J.J.; Chang, C.; Lovelock, M.; Higginson, D.S.; Mah, D.; Cahlon, O.; Powell, S. Exponential increase in relative biological effectiveness along distal edge of a proton Bragg peak as measured by deoxyribonucleic acid double-strand breaks. Int. J. Radiat. Oncol. Biol. Phys. 2016, 95, 62-69. [CrossRef]

83. Aoki-Nakano, M.; Furusawa, Y.; Uzawa, A.; Matsumoto, Y.; Hirayama, R.; Tsuruoka, C.; Ogino, T.; Nishio, T.; Kagawa, K.; Murakami, M.; et al. Relative biological effectiveness of therapeutic proton beams for HSG cells at Japanese proton therapy facilities. J. Radiat. Res. 2014, 55, 812-815. [CrossRef]

84. Carabe, A.; Karagounis, I.V.; Huynh, K.; Bertolet, A.; François, N.; Kim, M.M.; Maity, A.; Abel, E.; Dale, R. Radiobiological effectiveness difference of proton arc beams versus conventional proton and photon beams. Phys. Med. Biol. 2020. [CrossRef] [PubMed]

85. Britten, R.; Nazaryan, V.; Davis, L.K.; Klein, S.B.; Nichiporov, D.; Mendonca, M.S.; Wolanski, M.; Nie, X.; George, J.; Keppel, C.; et al. Variations in the RBE for cell killing along the depth-dose profile of a modulated proton therapy beam. Radiat. Res. 2013, 179, 21-28. [CrossRef] [PubMed] 
86. Ma, D.; Bronk, L.; Kerr, M.; Sobieski, M.; Chen, M.; Geng, C.; Yiu, J.; Wang, X.; Sahoo, N.; Cao, W.; et al. Exploring the advantages of intensity-modulated proton therapy: Experimental validation of biological effects using two different beam intensity-modulation patterns. Sci. Rep. 2020, 10, 1-13. [CrossRef]

87. Maeda, K.; Yasui, H.; Matsuura, T.; Yamamori, T.; Suzuki, M.; Nagane, M.; Nam, J.M.; Inanami, O.; Shirato, H. Evaluation of the relative biological effectiveness of spot-scanning proton irradiation in vitro. J. Radiat. Res. 2016. [CrossRef]

88. Wouters, B.; Lam, G.; Oelfke, U.; Gardey, K.; Durand, R.; Skarsgard, L. Measurements of relative biological effectiveness of the $70 \mathrm{MeV}$ proton beam at TRIUMF using Chinese hamster V79 cells and the high-precision cell sorter assay. Radiat. Res. 1996, 146, 159-170. [CrossRef]

89. Belli, M.; Cera, F.; Cherubini, R.; Dalla Vecchia, M.; Haque, A.; Ianzini, F.; Moschini, G.; Sapora, O.; Simone, G.; Tabocchini, M.; et al. RBE-LET relationships for cell inactivation and mutation induced by low energy protons in V79 cells: Further results at the LNL facility. Int. J. Radiat. Biol. 1998, 74, 501-509.

90. Kanemoto, A.; Hirayama, R.; Moritake, T.; Furusawa, Y.; Sun, L.; Sakae, T.; Kuno, A.; Terunuma, T.; Yasuoka, K.; Mori, Y.; et al. $\mathrm{RBE}$ and OER within the spread-out Bragg peak for proton beam therapy: In vitro study at the Proton Medical Research Center at the University of Tsukuba. J. Radiat. Res. 2014, 55, 1028-1032. [CrossRef]

91. Chaudhary, P.; Marshall, T.I.; Perozziello, F.M.; Manti, L.; Currell, F.J.; Hanton, F.; McMahon, S.J.; Kavanagh, J.N.; Cirrone, G.A.P.; Romano, F.; et al. Relative biological effectiveness variation along monoenergetic and modulated Bragg peaks of a 62-MeV therapeutic proton beam: A preclinical assessment. Int. J. Radiat. Oncol. Biol. Phys. 2014, 90, 27-35. [CrossRef]

92. Mara, E.; Clausen, M.; Khachonkham, S.; Deycmar, S.; Pessy, C.; Dörr, W.; Kuess, P.; Georg, D.; Gruber, S. Investigating the impact of alpha/beta and LETd on relative biological effectiveness in scanned proton beams: An in vitro study based on human cell lines. Med. Phys. 2020, 47, 3691-3702. [CrossRef]

93. Girdhani, S.; Lamont, C.; Hahnfeldt, P.; Abdollahi, A.; Hlatky, L. Proton irradiation suppresses angiogenic genes and impairs cell invasion and tumor growth. Radiat. Res. 2012, 178, 33-45. [CrossRef]

94. Lee, K.S.; Lee, D.H.; Chun, S.Y.; Nam, K.S. Metastatic potential in MDA-MB-231 human breast cancer cells is inhibited by proton beam irradiation via the Akt/nuclear factor- $\kappa$ B signaling pathway. Mol. Med. Rep. 2014, 10, 1007-1012. [CrossRef]

95. Lee, K.S.; Shin, J.S.; Nam, K.S. Effect of proton beam irradiation on the regulation of metastasis-enhancing factors in MCF-7 human breast cancer cells. J. Korean Phys. Soc. 2013, 63, 1373-1378. [CrossRef]

96. Lee, K.S.; Shin, J.S.; Nam, K.S.; Shon, Y.H. Anti-angiogenic activity in metastasis of human breast cancer cells irradiated by a proton beam. J. Korean Phys. Soc. 2012, 61, 268-272. [CrossRef]

97. Kyu-Shik, L.; Jin-Young, M.; Kyung-Soo, N.; Yun-Hee, S. Inhibition of metastatic activities in human breast cancer cells irradiated by a proton beam. J. Korean Phys. Soc. 2011, 59, 653.

98. Lühr, A.; von Neubeck, C.; Pawelke, J.; Seidlitz, A.; Peitzsch, C.; Bentzen, S.M.; Bortfeld, T.; Debus, J.; Deutsch, E.; Langendijk, J.A.; et al. "Radiobiology of Proton Therapy": Results of an international expert workshop. Radiother. Oncol. 2018, $128,56-67$. [CrossRef]

99. Hojo, H.; Dohmae, T.; Hotta, K.; Kageyama, S.I.; Baba, H.; Kohno, R.; Motegi, A.; Tsuchihara, K.; Akimoto, T. Effect of 5fluorouracil on cellular response to proton beam in esophageal cancer cell lines according to the position of spread-out Bragg peak. Acta Oncol. 2019. [CrossRef]

100. Iwata, H.; Shuto, T.; Kamei, S.; Omachi, K.; Moriuchi, M.; Omachi, C.; Toshito, T.; Hashimoto, S.; Nakajima, K.; Sugie, C.; et al Combined effects of cisplatin and photon or proton irradiation in cultured cells: Radiosensitization, patterns of cell death and cell cycle distribution. J. Radiat. Res. 2020. [CrossRef]

101. Wang, L.; Cao, J.; Wang, X.; Lin, E.; Wang, Z.; Li, Y.; Li, Y.; Chen, M.; Wang, X.; Jiang, B.; et al. Proton and photon radiosensitization effects of niraparib, a PARP-1/-2 inhibitor, on human head and neck cancer cells. Head Neck 2020, 42, 2244-2256. [CrossRef]

102. Amundson, S.A.; Do, K.T.; Vinikoor, L.C.; Lee, R.A.; Koch-Paiz, C.A.; Ahn, J.; Reimers, M.; Chen, Y.; Scudiero, D.A.; Weinstein, J.N.; et al. Integrating global gene expression and radiation survival parameters across the 60 cell lines of the National Cancer Institute Anticancer Drug Screen. Cancer Res. 2008, 68, 415-424. [CrossRef]

103. Liu, Q.; Wang, M.; Kern, A.M.; Khaled, S.; Han, J.; Yeap, B.Y.; Hong, T.S.; Settleman, J.; Benes, C.H.; Held, K.D.; et al. Adapting a drug screening platform to discover associations of molecular targeted radiosensitizers with genomic biomarkers. Mol. Cancer Res. 2015. [CrossRef]

104. Liu, Q.; Ghosh, P.; Magpayo, N.; Testa, M.; Tang, S.; Gheorghiu, L.; Biggs, P.; Paganetti, H.; Efstathiou, J.A.; Lu, H.M.; et al. Lung cancer cell line screen links fanconi anemia/BRCA pathway defects to increased relative biological effectiveness of proton radiation. Int. J. Radiat. Oncol. Biol. Phys. 2015, 91, 1081-1089. [CrossRef]

105. Russell, W.M.S.; Burch, R.L. The Principles of Humane Experimental Technique; Methuen \& Co LTD: London, UK, 1959.

106. Hirschhaeuser, F.; Menne, H.; Dittfeld, C.; West, J.; Mueller-Klieser, W.; Kunz-Schughart, L.A. Multicellular tumor spheroids: An underestimated tool is catching up again. J. Biotechnol. 2010, 148, 3-15. [CrossRef]

107. Vehlow, A.; Deville, S.S.; Cordes, N. 3D Radiation Biology for Identifying Radiosensitizers. In Molecular Targeted Radiosensitizers: Opportunities and Challenges; Willers, H., Eke, I., Eds.; Springer International Publishing: Cham, Switzerland, 2020; pp. 115-135. [CrossRef]

108. Zanoni, M.; Piccinini, F.; Arienti, C.; Zamagni, A.; Santi, S.; Polico, R.; Bevilacqua, A.; Tesei, A. 3D tumor spheroid models for in vitro therapeutic screening: A systematic approach to enhance the biological relevance of data obtained. Sci. Rep. 2016, 6, 1-11. [CrossRef] 
109. Friedrich, J.; Ebner, R.; Kunz-Schughart, L.A. Experimental anti-tumor therapy in 3-D: Spheroids-old hat or new challenge? Int. J. Radiat. Biol. 2007, 83, 849-871. [CrossRef] [PubMed]

110. Hehlgans, S.; Eke, I.; Deuse, Y.; Cordes, N. Integrin-linked kinase: Dispensable for radiation survival of three-dimensionally cultured fibroblasts. Radiother. Oncol. 2008, 86, 329-335. [CrossRef]

111. Chiblak, S.; Tang, Z.; Campos, B.; Gal, Z.; Unterberg, A.; Debus, J.; Herold-Mende, C.; Abdollahi, A. Radiosensitivity of patient-derived glioma stem cell 3-dimensional cultures to photon, proton, and carbon irradiation. Int. J. Radiat. Oncol. Biol. Phys. 2016, 95, 112-119. [CrossRef] [PubMed]

112. Mueller-Klieser, W. Tumor biology and experimental therapeutics. Crit. Rev. Oncol. 2000, 36, 123-139. [CrossRef]

113. Kunz-Schughart, L.A.; Freyer, J.P.; Hofstaedter, F.; Ebner, R. The use of 3-D cultures for high-throughput screening: The multicellular spheroid model. J. Biomol. Screen. 2004, 9, 273-285. [CrossRef]

114. Doctor, A.; Seifert, V.; Ullrich, M.; Hauser, S.; Pietzsch, J. Three-Dimensional Cell Culture Systems in Radiopharmaceutical Cancer Research. Cancers 2020, 12, 2765. [CrossRef]

115. Brüningk, S.C.; Rivens, I.; Box, C.; Oelfke, U.; Ter Haar, G. 3D tumour spheroids for the prediction of the effects of radiation and hyperthermia treatments. Sci. Rep. 2020, 10, 1-13. [CrossRef]

116. Durand, R.E.; Olive, P.L. Resistance of tumor cells to chemo-and radiotherapy modulated by the three-dimensional architecture of solid tumors and spheroids. Methods Cell Biol. 2001, 64, 211-233.

117. Shield, K.; Ackland, M.L.; Ahmed, N.; Rice, G.E. Multicellular spheroids in ovarian cancer metastases: Biology and pathology. Gynecol. Oncol. 2009, 113, 143-148. [CrossRef] [PubMed]

118. Seidlitz, T.; Merker, S.R.; Rothe, A.; Zakrzewski, F.; von Neubeck, C.; Grützmann, K.; Sommer, U.; Schweitzer, C.; Schölch, S.; Uhlemann, H.; et al. Human gastric cancer modelling using organoids. Gut 2019, 68, 207-217. [CrossRef]

119. Sato, T.; Vries, R.G.; Snippert, H.J.; Van De Wetering, M.; Barker, N.; Stange, D.E.; Van Es, J.H.; Abo, A.; Kujala, P.; Peters, P.J.; et al. Single Lgr5 stem cells build crypt-villus structures in vitro without a mesenchymal niche. Nature 2009, 459, 262-265. [CrossRef] [PubMed]

120. Sachs, N.; de Ligt, J.; Kopper, O.; Gogola, E.; Bounova, G.; Weeber, F.; Balgobind, A.V.; Wind, K.; Gracanin, A.; Begthel, H.; et al. A Living Biobank of Breast Cancer Organoids Captures Disease Heterogeneity. Cell 2018, 172, 373-386.e10. [CrossRef]

121. Linkous, A.; Balamatsias, D.; Snuderl, M.; Edwards, L.; Miyaguchi, K.; Milner, T.; Reich, B.; Cohen-Gould, L.; Storaska, A.; Nakayama, Y.; et al. Modeling Patient-Derived Glioblastoma with Cerebral Organoids. Cell Rep. 2019, 26, 3203-3211.e5. [CrossRef]

122. Artegiani, B.; Clevers, H. Use and application of 3D-organoid technology. Hum. Mol. Genet. 2018, 27, R99-R107. [CrossRef] [PubMed]

123. Driehuis, E.; Kolders, S.; Spelier, S.; Lõhmussaar, K.; Willems, S.M.; Devriese, L.A.; de Bree, R.; de Ruiter, E.J.; Korving, J.; Begthel, H.; et al. Oral Mucosal Organoids as a Potential Platform for Personalized Cancer Therapy. Cancer Discov. $2019,9,852-871$. [CrossRef]

124. Drost, J.; Clevers, H. Organoids in cancer research. Nat. Rev. Cancer 2018, 18, 407-418. [CrossRef]

125. Nagle, P.W.; Coppes, R.P. Current and Future Perspectives of the Use of Organoids in Radiobiology. Cells 2020, 9, 2649. [CrossRef] [PubMed]

126. Duarte, A.A.; Gogola, E.; Sachs, N.; Barazas, M.; Annunziato, S.; De Ruiter, J.; Velds, A.; Blatter, S.; Houthuijzen, J.M.; Van De Ven, M.; et al. BRCA-deficient mouse mammary tumor organoids to study cancer-drug resistance. Nat. Methods 2018, 15, 134-140. [CrossRef]

127. Martin, M.L.; Adileh, M.; Hsu, K.S.; Hua, G.; Lee, S.G.; Li, C.; Fuller, J.D.; Rotolo, J.A.; Bodo, S.; Klingler, S.; et al. Organoids Reveal That Inherent Radiosensitivity of Small and Large Intestinal Stem Cells Determines Organ Sensitivity. Cancer Res. 2020, 80, 1219-1227. [CrossRef] [PubMed]

128. Kretzschmar, K. Cancer research using organoid technology. J. Mol. Med. 2020, 99, 501-515. [CrossRef] [PubMed]

129. Boucherit, N.; Gorvel, L.; Olive, D. 3D Tumor Models and Their Use for the Testing of Immunotherapies. Front. Immunol. 2020, 11, 3220. [CrossRef]

130. Shannon, A.E.; Boos, C.E.; Hummon, A.B. Co-culturing multicellular tumor models: Modeling the tumor microenvironment and analysis techniques. Proteomics 2021, 21, 2000103. [CrossRef]

131. Lazzari, G.; Nicolas, V.; Matsusaki, M.; Akashi, M.; Couvreur, P.; Mura, S. Multicellular spheroid based on a triple co-culture: A novel 3D model to mimic pancreatic tumor complexity. Acta Biomater. 2018, 78, 296-307. [CrossRef]

132. Eke, I.; Cordes, N. Radiobiology goes 3D: How ECM and cell morphology impact on cell survival after irradiation. Radiother. Oncol. 2011, 99, 271-278. [CrossRef]

133. Meerz, A.; Deville, S.S.; Müller, J.; Cordes, N. Comparative Therapeutic Exploitability of Acute Adaptation Mechanisms to Photon and Proton Irradiation in 3D Head and Neck Squamous Cell Carcinoma Cell Cultures. Cancers 2021, 13, 1190. [CrossRef]

134. Walenta, S.; Mueller-Klieser, W. Differential superiority of heavy charged-particle irradiation to X-rays: Studies on biological effectiveness and side effect mechanisms in multicellular tumor and normal tissue models. Front. Oncol. 2016, 6, 30. [CrossRef]

135. Senavirathna, L.K.; Fernando, R.; Maples, D.; Zheng, Y.; Polf, J.C.; Ranjan, A. Tumor Spheroids as an In Vitro Model for Determining the Therapeutic Response to Proton Beam Radiotherapy and Thermally Sensitive Nanocarriers. Theranostics 2013, 3, 687. [CrossRef] [PubMed] 
136. Sorour, N.; Hussein, R.; Von Neubek, C.; Lühr, A.; Staysk, O.; Kunz-Schughart, L. PO-247 Beneficial therapeutic ménage à trois: Enzymotherapeutic arginine-deprivation, gemcitabine and proton irradiation for pancreatic cancer treatment-a systematic in vitro study. ESMO Open 2018, 3, A117. [CrossRef]

137. Vitti, E.T.; Kacperek, A.; Parsons, J.L. Targeting DNA double-strand break repair enhances radiosensitivity of HPV-positive and HPV-negative head and neck squamous cell carcinoma to photons and protons. Cancers 2020, 12, 1490. [CrossRef] [PubMed]

138. Nomura, K.; Iwata, H.; Toshito, T.; Omachi, C.; Nagayoshi, J.; Nakajima, K.; Ogino, H.; Shibamoto, Y. Biological effects of passive scattering and spot scanning proton beams at the distal end of the spread-out Bragg peak in single cells and multicell spheroids. Int. J. Radiat. Biol. 2021, 97, 695-703. [CrossRef]

139. Iwata, H.; Toshito, T.; Omachi, C.; Umezawa, M.; Shinozawa, Y.; Yamada, M.; Nakajima, K.; Nomura, K.; Ogino, H.; Shibamoto, Y. Scanning Proton FLASH Irradiation Using a Synchrotron Accelerator: Effects on Cultured Cells and Differences by Irradiation Positions. Int. J. Radiat. Oncol. Biol. Phys. 2020, 108, e522. [CrossRef]

140. Nanduri, L.S.; Maimets, M.; Pringle, S.A.; Van Der Zwaag, M.; Van Os, R.P.; Coppes, R.P. Regeneration of irradiated salivary glands with stem cell marker expressing cells. Radiother. Oncol. 2011, 99, 367-372. [CrossRef]

141. Nagle, P.W.; Hosper, N.A.; Ploeg, E.M.; van Goethem, M.J.; Brandenburg, S.; Langendijk, J.A.; Chiu, R.K.; Coppes, R.P. The In Vitro Response of Tissue Stem Cells to Irradiation with Different Linear Energy Transfers. Int. J. Radiat. Oncol. Biol. Phys. 2016, 95, 103-111. [CrossRef]

142. Hacker, B.C.; Gomez, J.D.; Batista, C.A.S.; Rafat, M. Growth and Characterization of Irradiated Organoids from Mammary Glands. JoVE J. Vis. Exp. 2019, e59293. [CrossRef]

143. Nagle, P.W.; van Goethem, M.J.; Kempers, M.; Kiewit, H.; Knopf, A.; Langendijk, J.A.; Brandenburg, S.; van Luijk, P.; Coppes, R.P. In vitro biological response of cancer and normal tissue cells to proton irradiation not affected by an added magnetic field. Radiother. Oncol. 2019, 137, 125-129. [CrossRef]

144. Yao, Y.; Xu, X.; Yang, L.; Zhu, J.; Wan, J.; Shen, L.; Xia, F.; Fu, G.; Deng, Y.; Pan, M.; et al. Patient-Derived Organoids Predict Chemoradiation Responses of Locally Advanced Rectal Cancer. Cell Stem Cell 2020, 26, 17-26.e6. [CrossRef]

145. Ganesh, K.; Wu, C.; O’Rourke, K.P.; Szeglin, B.C.; Zheng, Y.; Sauvé, C.E.G.; Adileh, M.; Wasserman, I.; Marco, M.R.; Kim, A.S.; et al. A rectal cancer organoid platform to study individual responses to chemoradiation. Nat. Med. 2019, 25, 1607-1614. [CrossRef]

146. Jacob, F.; Salinas, R.D.; Zhang, D.Y.; Nguyen, P.T.; Schnoll, J.G.; Wong, S.Z.H.; Thokala, R.; Sheikh, S.; Saxena, D.; Prokop, S.; et al. A Patient-Derived Glioblastoma Organoid Model and Biobank Recapitulates Inter- and Intra-tumoral Heterogeneity. Cell 2020, 180, 188-204.e22. [CrossRef]

147. Eke, I.; Hehlgans, S.; Sandfort, V.; Cordes, N. 3D matrix-based cell cultures: Automated analysis of tumor cell survival and proliferation. Int. J. Oncol. 2016, 48, 313-321. [CrossRef]

148. Friedrich, J.; Eder, W.; Castaneda, J.; Doss, M.; Huber, E.; Ebner, R.; Kunz-Schughart, L.A. A reliable tool to determine cell viability in complex 3-d culture: The acid phosphatase assay. J. Biomol. Screen. 2007, 12, 925-937. [CrossRef]

149. Friedrich, J.; Seidel, C.; Ebner, R.; Kunz-Schughart, L.A. Spheroid-based drug screen: Considerations and practical approach. Nat. Protoc. 2009, 4, 309. [CrossRef]

150. Ingargiola, M.; Runge, R.; Heldt, J.M.; Freudenberg, R.; Steinbach, J.; Cordes, N.; Baumann, M.; Kotzerke, J.; Brockhoff, G.; Kunz-Schughart, L. Potential of a Cetuximab-based radioimmunotherapy combined with external irradiation manifests in a 3-D cell assay. Int. J. Cancer 2014, 135, 968-980. [CrossRef]

151. Chen, O.; Michlíková, S.; Eckhardt, L.; Wondrak, M.; De Mendoza, A.M.; Krause, M.; McLeod, D.D.; Kunz-Schughart, L.A. Efficient Heat Shock Response Affects Hyperthermia-Induced Radiosensitization in a Tumor Spheroid Control Probability Assay. Cancers 2021, 13, 3168. [CrossRef] [PubMed]

152. Hinrichs, C.N.; Ingargiola, M.; Käubler, T.; Löck, S.; Temme, A.; Köhn-Luque, A.; Deutsch, A.; Vovk, O.; Stasyk, O.; KunzSchughart, L.A. Arginine Deprivation Therapy: Putative Strategy to Eradicate Glioblastoma Cells by Radiosensitization. Mol. Cancer Ther. 2018, 17, 393-406. [CrossRef] [PubMed]

153. Budach, W.; Budach, V.; Stuschke, M.; Dinges, S.; Sack, H. The TCD50 and regrowth delay assay in human tumor xenografts: differences and implications. Int. J. Radiat. Oncol. Biol. Phys. 1993, 25, 259-268. [CrossRef]

154. Koch, U.; Höhne, K.; Von Neubeck, C.; Thames, H.D.; Yaromina, A.; Dahm-Daphi, J.; Baumann, M.; Krause, M. Residual $\gamma \mathrm{H} 2 \mathrm{AX}$ foci predict local tumour control after radiotherapy. Radiother. Oncol. 2013, 108, 434-439. [CrossRef] [PubMed]

155. Rassamegevanon, T.; Löck, S.; Baumann, M.; Krause, M.; von Neubeck, C. Comparable radiation response of ex vivo and in vivo irradiated tumor samples determined by residual $\gamma \mathrm{H} 2 \mathrm{AX}$. Radiother. Oncol. 2019, 139, 94-100. [CrossRef]

156. Humpel, C. Organotypic brain slice cultures: A review. Neuroscience 2015, 305, 86-98. [CrossRef]

157. Hofmann, F.; Bläsche, R.; Kasper, M.; Barth, K. A co-culture system with an organotypic lung slice and an immortal alveolar macrophage cell line to quantify silica-induced inflammation. PLoS ONE 2015, 10, e0117056. [CrossRef]

158. Brandenburger, M.; Wenzel, J.; Bogdan, R.; Richardt, D.; Nguemo, F.; Reppel, M.; Hescheler, J.; Terlau, H.; Dendorfer, A. Organotypic slice culture from human adult ventricular myocardium. Cardiovasc. Res. 2012, 93, 50-59. [CrossRef] [PubMed]

159. Meijer, T.G.; Naipal, K.A.; Jager, A.; van Gent, D.C. Ex vivo tumor culture systems for functional drug testing and therapy response prediction. Future Sci. OA 2017, 3, FSO190. [CrossRef] [PubMed]

160. Yoshida, Y.; Suzuki, Y.; Al-Jahdari, W.S.; Hamada, N.; Funayama, T.; Shirai, K.; Katoh, H.; Sakashita, T.; Kobayashi, Y.; Nakano, T. Evaluation of the relative biological effectiveness of carbon ion beams in the cerebellum using the rat organotypic slice culture system. J. Radiat. Res. 2012, 53, 87-92. [CrossRef] [PubMed] 
161. Vaira, V.; Fedele, G.; Pyne, S.; Fasoli, E.; Zadra, G.; Bailey, D.; Snyder, E.; Faversani, A.; Coggi, G.; Flavin, R.; et al. Preclinical model of organotypic culture for pharmacodynamic profiling of human tumors. Proc. Natl. Acad. Sci. USA 2010, 107, 8352-8356. [CrossRef]

162. Bayin, N.S.; Ma, L.; Thomas, C.; Baitalmal, R.; Sure, A.; Fansiwala, K.; Bustoros, M.; Golfinos, J.G.; Pacione, D.; Snuderl, M.; et al. Patient-specific screening using high-grade glioma explants to determine potential radiosensitization by a TGF- $\beta$ small molecule inhibitor. Neoplasia 2016, 18, 795-805. [CrossRef]

163. Merz, F.; Gaunitz, F.; Dehghani, F.; Renner, C.; Meixensberger, J.; Gutenberg, A.; Giese, A.; Schopow, K.; Hellwig, C.; Schäfer, M.; et al. Organotypic slice cultures of human glioblastoma reveal different susceptibilities to treatments. Neuro Oncol. 2013, 15, 670-681. [CrossRef]

164. Parker, J.J.; Canoll, P.; Niswander, L.; Kleinschmidt-DeMasters, B.; Foshay, K.; Waziri, A. Intratumoral heterogeneity of endogenous tumor cell invasive behavior in human glioblastoma. Sci. Rep. 2018, 8, 1-10. [CrossRef]

165. Chadwick, E.J.; Yang, D.P.; Filbin, M.G.; Mazzola, E.; Sun, Y.; Behar, O.; Pazyra-Murphy, M.F.; Goumnerova, L.; Ligon, K.L.; Stiles, C.D.; et al. A brain tumor/organotypic slice co-culture system for studying tumor microenvironment and targeted drug therapies. J. Vis. Exp. JoVE 2015. [CrossRef]

166. Eisemann, T.; Costa, B.; Strelau, J.; Mittelbronn, M.; Angel, P.; Peterziel, H. An advanced glioma cell invasion assay based on organotypic brain slice cultures. BMC Cancer 2018, 18, 1-10. [CrossRef]

167. Roife, D.; Dai, B.; Kang, Y.; Perez, M.V.R.; Pratt, M.; Li, X.; Fleming, J.B. Ex vivo testing of patient-derived xenografts mirrors the clinical outcome of patients with pancreatic ductal adenocarcinoma. Clin. Cancer Res. 2016, 22, 6021-6030. [CrossRef]

168. Merz, F.; Müller, M.; Taucher-Scholz, G.; Rödel, F.; Stöcker, H.; Schopow, K.; Laprell, L.; Dehghani, F.; Durante, M.; Bechmann, I. Tissue slice cultures from humans or rodents: A new tool to evaluate biological effects of heavy ions. Radiat. Environ. Biophys. 2010, 49, 457-462. [CrossRef] [PubMed]

169. Mewes, A.; Franke, H.; Singer, D. Organotypic brain slice cultures of adult transgenic P301S mice-A model for tauopathy studies. PLOS ONE 2012, 7, e45017.

170. Davies, E.J.; Dong, M.; Gutekunst, M.; Närhi, K.; Van Zoggel, H.J.; Blom, S.; Nagaraj, A.; Metsalu, T.; Oswald, E.; Erkens-Schulze, S.; et al. Capturing complex tumour biology in vitro: Histological and molecular characterisation of precision cut slices. Sci. Rep. 2015, 5, 1-17. [CrossRef]

171. Schmid, T.E.; Dollinger, G.; Hable, V.; Greubel, C.; Zlobinskaya, O.; Michalski, D.; Molls, M.; Röper, B. Relative biological effectiveness of pulsed and continuous $20 \mathrm{MeV}$ protons for micronucleus induction in 3D human reconstructed skin tissue. Radiother. Oncol. 2010, 95, 66-72. [CrossRef]

172. Zlobinskaya, O.; Girst, S.; Greubel, C.; Hable, V.; Siebenwirth, C.; Walsh, D.W.; Multhoff, G.; Wilkens, J.J.; Schmid, T.E.; Dollinger, G. Reduced side effects by proton microchannel radiotherapy: Study in a human skin model. Radiat. Environ. Biophys. 2013, 52, 123-133. [CrossRef] [PubMed]

173. Hamdi, D.H.; Barbieri, S.; Chevalier, F.; Groetz, J.E.; Legendre, F.; Demoor, M.; Galera, P.; Lefaix, J.L.; Saintigny, Y. In vitro engineering of human 3D chondrosarcoma: A preclinical model relevant for investigations of radiation quality impact. BMC Cancer 2015, 15, 1-14. [CrossRef] [PubMed]

174. Quan, Y.; Sun, M.; Tan, Z.; Eijkel, J.C.; Van Den Berg, A.; Van Der Meer, A.; Xie, Y. Organ-on-a-chip: The next generation platform for risk assessment of radiobiology. RSC Adv. 2020, 10, 39521-39530. [CrossRef]

175. Jalili-Firoozinezhad, S.; Prantil-Baun, R.; Jiang, A.; Potla, R.; Mammoto, T.; Weaver, J.C.; Ferrante, T.C.; Kim, H.J.; Cabral, J.M.; Levy, O.; et al. Modeling radiation injury-induced cell death and countermeasure drug responses in a human Gut-on-a-Chip. Cell Death Dis. 2018, 9, 1-14. [CrossRef] [PubMed]

176. Torisawa, Y.s.; Mammoto, T.; Jiang, E.; Jiang, A.; Mammoto, A.; Watters, A.L.; Bahinski, A.; Ingber, D.E. Modeling hematopoiesis and responses to radiation countermeasures in a bone marrow-on-a-chip. Tissue Eng. Part C Methods 2016, 22, 509-515. [CrossRef] [PubMed]

177. Watanabe-Asaka, T.; Mukai, C.; Mitani, H. Technologies and analyses using medaka to evaluate effects of space on health. Biol. Sci. Space 2010, 24, 3-9. [CrossRef]

178. Barriuso, J.; Nagaraju, R.; Hurlstone, A. Zebrafish: A new companion for translational research in oncology. Clin. Cancer Res. 2015, 21, 969-975. [CrossRef]

179. Geiger, G.A.; Parker, S.E.; Beothy, A.P.; Tucker, J.A.; Mullins, M.C.; Kao, G.D. Zebrafish as a “biosensor”? Effects of ionizing radiation and amifostine on embryonic viability and development. Cancer Res. 2006, 66, 8172-8181. [CrossRef]

180. Pérez-Gélvez, Y.; Unger, S.; Gutiérrez-Sánchez, G.; Bridger, R.; Rhodes, O.E.; Bergmann, C. An Effective Protocol for Proteome Analysis of Medaka (Oryzias latipes) after Acute Exposure to Ionizing Radiation. Methods Protoc. 2019, 2, 66. [CrossRef] [PubMed]

181. Li, X.; Zha, X.; Wang, Y.; Jia, R.; Hu, B.; Zhao, B. Toxic effects and foundation of proton radiation on the early-life stage of zebrafish development. Chemosphere 2018, 200, 302-312. [CrossRef] [PubMed]

182. Nagata, K.; Hashimoto, C.; Watanabe-Asaka, T.; Itoh, K.; Yasuda, T.; Ohta, K.; Oonishi, H.; Igarashi, K.; Suzuki, M.; Funayama, T.; et al. In vivo 3D analysis of systemic effects after local heavy-ion beam irradiation in an animal model. Sci. Rep. 2016, 6, 1-9. [CrossRef] [PubMed]

183. McAleer, M.F.; Davidson, C.; Davidson, W.R.; Yentzer, B.; Farber, S.A.; Rodeck, U.; Dicker, A.P. Novel use of zebrafish as a vertebrate model to screen radiation protectors and sensitizers. Int. J. Radiat. Oncol. Biol. Phys. 2005, 61, 10-13. [CrossRef] [PubMed] 
184. Beyreuther, E.; Brand, M.; Hans, S.; Hideghéty, K.; Karsch, L.; Leßmann, E.; Schürer, M.; Szabó, E.R.; Pawelke, J. Feasibility of proton FLASH effect tested by zebrafish embryo irradiation. Radiother. Oncol. 2019, 139, 46-50. [CrossRef]

185. Choi, V.W.Y.; Ng, C.Y.P.; Kobayashi, A.; Konishi, T.; Oikawa, M.; Cheng, S.H.; Yu, P.K.N. Exogenous carbon monoxide suppresses adaptive response induced in zebrafish embryos in vivo by microbeam protons. J. Radiat. Res. 2014, 55, i115. [CrossRef]

186. Jang, G.H.; Ha, J.H.; Huh, T.L.; Lee, Y.M. Effect of proton beam on blood vessel formation in early developing zebrafish (Danio rerio) embryos. Arch. Pharmacal Res. 2008, 31, 779-785. [CrossRef]

187. Costa, B.; Ferreira, S.; Póvoa, V.; Cardoso, M.J.; Vieira, S.; Stroom, J.; Fidalgo, P.; Rio-Tinto, R.; Figueiredo, N.; Parés, O.; et al. Developments in zebrafish avatars as radiotherapy sensitivity reporters-towards personalized medicine. EBioMedicine 2020, 51, 102578. [CrossRef]

188. Mercatali, L.; La Manna, F.; Groenewoud, A.; Casadei, R.; Recine, F.; Miserocchi, G.; Pieri, F.; Liverani, C.; Bongiovanni, A.; Spadazzi, C.; et al. Development of a patient-derived xenograft (PDX) of breast cancer bone metastasis in a zebrafish model. Int. J. Mol. Sci. 2016, 17, 1375. [CrossRef] [PubMed]

189. Wu, J.Q.; Zhai, J.; Li, C.Y.; Tan, A.M.; Wei, P.; Shen, L.Z.; He, M.F. Patient-derived xenograft in zebrafish embryos: A new platform for translational research in gastric cancer. J. Exp. Clin. Cancer Res. 2017, 36, 1-10. [CrossRef]

190. Cacao, E.; Parihar, V.K.; Limoli, C.L.; Cucinotta, F.A. Stochastic Modeling of Radiation-induced Dendritic Damage on in silico Mouse Hippocampal Neurons. Sci. Rep. 2018, 8, 5494. [CrossRef] [PubMed]

191. Al-Samadi, A.; Tuomainen, K.; Kivimäki, A.; Salem, A.; Al-Kubati, S.; Hyytiäinen, A.; Parikka, M.; Mesimäki, K.; Wilkman, T.; Mäkitie, A.; et al. PCR-based zebrafish model for personalised medicine in head and neck cancer. J. Transl. Med. 2019, 17, 1-6. [CrossRef] [PubMed]

192. Quinn, T.J.; Ding, X.; Li, X.; Wilson, G.D.; Buelow, K.; Sivananthan, A.; Thermozier, S.; Henderson, A.; Epperly, M.W.; Franicola, D.; et al. Amelioration of mucositis in proton therapy of fanconi anemia Fanca-/- mice by JP4-039. In Vivo 2019, 33, 1757-1766. [CrossRef]

193. Kim, S.S.; Choo, D.W.; Shin, D.; Baek, H.J.; Kim, T.H.; Motoyama, N.; De Coster, B.M.; Gueulette, J.; Furusawa, Y.; Ando, K.; et al. In vivo radiobiological characterization of proton beam at the National Cancer Center in Korea: Effect of the Chk2 mutation. Int. J. Radiat. Oncol. Biol. Phys. 2011, 79, 559-562. [CrossRef]

194. Tatsuzaki, H.; Inada, T.; Shimizu, T.; Arimoto, T.; Satoh, S.; Akisada, M. Early skin reaction following $250 \mathrm{MeV}$ proton peak irradiation. J. Radiat. Res. 1987, 28, 150-155. [CrossRef]

195. Tatsuzaki, H.; Arimoto, T.; Inada, T.; Uwamino, Y.; Nakamura, T.; Yaguchi, M.; Akisada, M. Early skin reaction following superficial proton irradiation. J. Radiat. Res. 1991, 32, 175-180. [CrossRef] [PubMed]

196. Urano, M.; Goitein, M.; Verhey, L.; Mendiondo, O.; Suit, H.D.; Koehler, A. Relative biological effectiveness of a high energy modulated proton beam using a spontaneous murine tumor in vivo. Int. J. Radiat. Oncol. Biol. Phys. 1980, 6, 1187-1193. [CrossRef]

197. Gueulette, J.; Slabbert, J.P.; Böhm, L.; De Coster, B.M.; Rosier, J.F.; Octave-Prignot, M.; Ruifrok, A.; Schreuder, A.N.; Wambersie, A.; Scalliet, P.; et al. Proton RBE for early intestinal tolerance in mice after fractionated irradiation. Radiother. Oncol. 2001, 61, 177-184. [CrossRef]

198. Bijl, H.P.; van Luijk, P.; Coppes, R.P.; Schippers, J.M.; Konings, A.W.; van der Kogel, A.J. Influence of adjacent low-dose fields on tolerance to high doses of protons in rat cervical spinal cord. Int. J. Radiat. Oncol. Biol. Phys. 2006, 64, 1204-1210. [CrossRef] [PubMed]

199. Bijl, H.P.; van Luijk, P.; Coppes, R.P.; Schippers, J.M.; Konings, A.W.; van der Kogel, A.J. Unexpected changes of rat cervical spinal cord tolerance caused by inhomogeneous dose distributions. Int. J. Radiat. Oncol. Biol. Phys. 2003, 57, 274-281. [CrossRef]

200. Bijl, H.P.; van Luijk, P.; Coppes, R.P.; Schippers, J.M.; Konings, A.W.; van der Kogel, A.J. Dose-volume effects in the rat cervical spinal cord after proton irradiation. Int. J. Radiat. Oncol. Biol. Phys. 2002, 52, 205-211. [CrossRef]

201. Bööj, S.; Dahlström, A.; Larsson, P.A.; Rosander, K.; Rosengren, B. Effects of proton irradiation of the lumbar intumescence on intra-axonal transport of acetylcholine and cholinergic enzymes in rat sciatic nerve. Acta Radiol. Oncol. 1980, 19, 387-393. [CrossRef]

202. Sténson, S. Weight Change and Mortality of Rats After Abdominal Proton and Roentgen Irradiation: A comparative investigation. Acta Radiol. Ther. Phys. Biol. 1969, 8, 423-432. [CrossRef]

203. Sténson, S. Effects of proton and roentgen radiation on the rectum of the rat. Acta Radiol. Ther. Phys. Biol. 1969, 8, 263-278. [CrossRef]

204. van der Kogel, A.J. Radiation tolerance of the rat spinal cord: Time-dose relationships. Radiology 1977, 122, 505-509. [CrossRef]

205. Innes, J.; Carsten, A. Demyelinating or Malacic Myelopathy: A Delayed Effect of Localized X-Irradiation in Experimental Rats. Arch. Neurol. 1961, 4, 190-199. [CrossRef]

206. Withers, H.; Elkind, M. Microcolony survival assay for cells of mouse intestinal mucosa exposed to radiation. Int. J. Radiat. Biol. Relat. Stud. Phys. Chem. Med. 1970, 17, 261-267. [CrossRef] [PubMed]

207. Choi, C.; Lee, C.; Shin, S.W.; Kim, S.Y.; Hong, S.N.; Park, H.C. Comparison of Proton and Photon Beam Irradiation in RadiationInduced Intestinal Injury Using a Mouse Model. Int. J. Mol. Sci. 2019, 20, 1894. [CrossRef] [PubMed]

208. Gueulette, J.; Octave-Prignot, M.; De Coster, B.M.; Wambersie, A.; Grégoire, V. Intestinal crypt regeneration in mice: A biological system for quality assurance in non-conventional radiation therapy. Radiother. Oncol. 2004, 73, S148-S154. [CrossRef]

209. Mason, K.A.; Gillin, M.T.; Mohan, R.; Cox, J.D. Preclinical biologic assessment of proton beam relative biologic effectiveness at Proton Therapy Center Houston. Int. J. Radiat. Oncol. Biol. Phys. 2007, 68, 968-970. [CrossRef] 
210. Gueulette, J.; Grégoire, V.; Octave-Prignot, M.; Wambersie, A. Measurements of radiobiological effectiveness in the $85 \mathrm{MeV}$ proton beam produced at the cyclotron CYCLONE of Louvain-la-Neuve, Belgium. Radiat. Res. 1996, 145, 70-74. [CrossRef]

211. Gueulette, J.; Blattmann, H.; Pedroni, E.; Coray, A.; De Coster, B.M.; Mahy, P.; Wambersie, A.; Goitein, G. Relative biologic effectiveness determination in mouse intestine for scanning proton beam at Paul Scherrer Institute, Switzerland. Influence of motion. Int. J. Radiat. Oncol. Biol. Phys. 2005, 62, 838-845. [CrossRef]

212. Gueulette, J.; Böhm, L.; De Coster, B.M.; Vynckier, S.; Octave-Prignot, M.; Schreuder, A.N.; Symons, J.E.; Jones, D.T.; Wambersie, A.; Scalliet, P. RBE variation as a function of depth in the $200-\mathrm{MeV}$ proton beam produced at the National Accelerator Centre in Faure (South Africa). Radiother. Oncol. 1997, 42, 303-309. [CrossRef]

213. Pecaut, M.J.; Haerich, P.; Zuccarelli, C.N.; Smith, A.L.; Zendejas, E.D.; Nelson, G.A. Behavioral consequences of radiation exposure to simulated space radiation in the C57BL/6 mouse: Open field, rotorod, and acoustic startle. Cogn. Affect. Behav. Neurosci. 2002, 2, 329-340. [CrossRef]

214. Williams, M.T.; Sugimoto, C.; Regan, S.L.; Pitzer, E.M.; Fritz, A.L.; Mascia, A.E.; Sertorio, M.; Vatner, R.E.; Perentesis, J.P.; Vorhees, C.V. Whole brain proton irradiation in adult Sprague Dawley rats produces dose dependent and non-dependent cognitive, behavioral, and dopaminergic effects. Sci. Rep. 2020, 10, 1-20. [CrossRef]

215. Takai, N.; Ohgami, M.; Ando, K.; Uzawa, A.; Hirayama, R.; Nakamura, S.; Ohba, Y. The focal brain proton beam irradiation insult in rats-Induced memory disturbance related change in acetylcholine receptor binding. RAD Conf. Proc. 2017, 2, 25-29.

216. Switzer III, R.; Bogo, V.; Mickley, G. Histologic effects of high energy electron and proton irradiation of rat brain detected with a silver-degeneration stain. Adv. Space Res. 1994, 14, 443-451. [CrossRef]

217. Lundqvist, H.; Rosander, K.; Lomanov, M.; Lukjashin, V.; Shimchuk, G.; Zolotov, V.; Minakova, E. Permeability of the blood-brain barrier in the rat after local proton irradiation. Acta Radiol. Oncol. 1982, 21, 267-271. [CrossRef]

218. Diffenderfer, E.S.; Verginadis, I.I.; Kim, M.M.; Shoniyozov, K.; Velalopoulou, A.; Goia, D.; Putt, M.; Hagan, S.; Avery, S.; Teo, K.; et al. Design, implementation, and in vivo validation of a novel proton FLASH radiation therapy system. Int. J. Radiat. Oncol. Biol. Phys. 2020, 106, 440-448. [CrossRef]

219. Cunningham, S.; McCauley, S.; Vairamani, K.; Speth, J.; Girdhani, S.; Abel, E.; Sharma, R.A.; Perentesis, J.P.; Wells, S.I.; Mascia, A.; et al. FLASH Proton Pencil Beam Scanning Irradiation Minimizes Radiation-Induced Leg Contracture and Skin Toxicity in Mice. Cancers 2021, 13, 1012. [CrossRef] [PubMed]

220. Nielsen, S.; Bassler, N.; Grzanka, L.; Swakon, J.; Olko, P.; Horsman, M.R.; Sørensen, B.S. Proton scanning and X-ray beam irradiation induce distinct regulation of inflammatory cytokines in a preclinical mouse model. Int. J. Radiat. Biol. 2020, 96, 1238-1244. [CrossRef] [PubMed]

221. Ricciotti, E.; Sarantopoulou, D.; Grant, G.R.; Sanzari, J.K.; Krigsfeld, G.S.; Kiliti, A.J.; Kennedy, A.R.; Grosser, T. Distinct vascular genomic response of proton and gamma radiation-A pilot investigation. PLoS ONE 2019, 14, e0207503. [CrossRef]

222. Finnberg, N.; Wambi, C.; Ware, J.H.; Kennedy, A.R. Gamma-radiation (GR) triggers a unique gene expression profile associated with cell death compared to proton radiation (PR) in mice in vivo. Cancer Biol. Ther. 2008, 7, 2023-2033. [CrossRef] [PubMed]

223. Wood, D.; Cox, A.; Hardy, K.; Salmon, Y.; Trotter, R. Head and neck tumors after energetic proton irradiation in rats. Adv. Space Res. 1994, 14, 681-684. [CrossRef]

224. Burns, F.; Albert, R.; Bennett, P.; Sinclair, I. Tumor incidence in rat skin after proton irradiation in a sieve pattern. Radiat. Res. 1972, 50, 181-190. [CrossRef]

225. Kwon, Y.S.; Lee, K.S.; Chun, S.Y.; Jang, T.J.; Nam, K.S. Suppressive effects of a proton beam on tumor growth and lung metastasis through the inhibition of metastatic gene expression in 4T1 orthotopic breast cancer model. Int. J. Oncol. 2016, 49, 336-342. [CrossRef]

226. Lamirault, C.; Brisebard, E.; Patriarca, A.; Juchaux, M.; Crepin, D.; Labiod, D.; Pouzoulet, F.; Sebrie, C.; Jourdain, L.; Le Dudal, M.; et al. Spatially Modulated Proton Minibeams Results in the Same Increase of Lifespan as a Uniform Target Dose Coverage in F98-Glioma-Bearing Rats. Radiat. Res. 2020, 194, 715-723. [CrossRef] [PubMed]

227. Prezado, Y.; Jouvion, G.; Patriarca, A.; Nauraye, C.; Guardiola, C.; Juchaux, M.; Lamirault, C.; Labiod, D.; Jourdain, L.; Sebrie, C.; et al. Proton minibeam radiation therapy widens the therapeutic index for high-grade gliomas. Sci. Rep. 2018, 8, 1-10. [CrossRef] [PubMed]

228. Prezado, Y.; Jouvion, G.; Guardiola, C.; Gonzalez, W.; Juchaux, M.; Bergs, J.; Nauraye, C.; Labiod, D.; De Marzi, L.; Pouzoulet, F.; et al. Tumor control in RG2 glioma-bearing rats: A comparison between proton minibeam therapy and standard proton therapy. Int. J. Radiat. Oncol. Biol. Phys. 2019, 104, 266-271. [CrossRef] [PubMed]

229. Gridley, D.S.; Miller, G.M.; Luo, X.; Cao, J.D.; Timiryasova, T.M.; Fodor, I.; Slater, J.M. Proton radiation and TNF- $\alpha /$ Bax gene therapy for orthotopic C6 brain tumor in Wistar rats. Technol. Cancer Res. Treat. 2004, 3, 217-227. [CrossRef]

230. Bibby, M. Orthotopic models of cancer for preclinical drug evaluation: Advantages and disadvantages. Eur. J. Cancer 2004, 40, 852-857. [CrossRef]

231. Lupu-Plesu, M.; Claren, A.; Martial, S.E.; N'diaye, P.; Lebrigand, K.; Pons, N.; Ambrosetti, D.; Peyrottes, I.; Feuillade, J.; Hérault, J.; et al. Effects of proton versus photon irradiation on (lymph) angiogenic, inflammatory, proliferative and anti-tumor immune responses in head and neck squamous cell carcinoma. Oncogenesis 2017, 6, e354. [CrossRef]

232. Cammarata, F.P.; Forte, G.I.; Broggi, G.; Bravatà, V.; Minafra, L.; Pisciotta, P.; Calvaruso, M.; Tringali, R.; Tomasello, B.; Torrisi, F.; et al. Molecular Investigation on a Triple Negative Breast Cancer Xenograft Model Exposed to Proton Beams. Int. J. Mol. Sci. 2020, 21, 6337. [CrossRef] 
233. Zlobinskaya, O.; Siebenwirth, C.; Greubel, C.; Hable, V.; Hertenberger, R.; Humble, N.; Reinhardt, S.; Michalski, D.; Röper, B.; Multhoff, G.; et al. The effects of ultra-high dose rate proton irradiation on growth delay in the treatment of human tumor xenografts in nude mice. Radiat. Res. 2014, 181, 177-183. [CrossRef]

234. Waissi, W.; Nicol, A.; Jung, M.; Rousseau, M.; Jarnet, D.; Noel, G.; Burckel, H. Radiosensitizing Pancreatic Cancer with PARP Inhibitor and Gemcitabine: An In Vivo and a Whole-Transcriptome Analysis after Proton or Photon Irradiation. Cancers 2021, 13, 527. [CrossRef]

235. Müller, C.; Leal, M.D.P.; Dominietto, M.D.; Umbricht, C.A.; Safai, S.; Perrin, R.L.; Egloff, M.; Bernhardt, P.; Meulen, N.P.D.; Weber, D.C.; et al. Combination of proton therapy and radionuclide therapy in mice: Preclinical pilot study at the paul scherrer institute. Pharmaceutics 2019, 11, 450. [CrossRef]

236. Melzig, C.; Golestaneh, A.F.; Mier, W.; Schwager, C.; Das, S.; Schlegel, J.; Lasitschka, F.; Kauczor, H.U.; Debus, J.; Haberkorn, U.; et al. Combined external beam radiotherapy with carbon ions and tumor targeting endoradiotherapy. Oncotarget 2018, 9, 29985-30004. [CrossRef]

237. Dietrich, A.; Andreeff, M.; Koi, L.; Bergmann, R.; Schubert, M.; Schreiner, L.; Löck, S.; Sihver, W.; Freudenberg, R.; Hering, S.; et al. Radiotherapy enhances uptake and efficacy of 90Y-cetuximab: A preclinical trial. Radiother. Oncol. 2021, 155, 285-292. [CrossRef]

238. Kamili, A.; Gifford, A.J.; Li, N.; Mayoh, C.; Chow, S.O.; Failes, T.W.; Eden, G.L.; Cadiz, R.; Xie, J.; Lukeis, R.E.; et al. Accelerating development of high-risk neuroblastoma patient-derived xenograft models for preclinical testing and personalised therapy. $\mathrm{Br}$. J. Cancer 2020, 122, 680-691. [CrossRef]

239. Morton, J.J.; Bird, G.; Refaeli, Y.; Jimeno, A. Humanized mouse xenograft models: Narrowing the tumor-microenvironment gap. Cancer Res. 2016, 76, 6153-6158. [CrossRef] [PubMed]

240. Feasibility Study of FLASH Radiotherapy for the Treatment of Symptomatic Bone Metastases (FAST-01). 2021. Available online: https: / / www.clinicaltrials.gov/ct2/ show / NCT04592887 (accessed on 4 August 2021).

241. Kirkman, H. Estrogen-Induced Tumors of the Kidney in the Syrian Hamster; Number 1-3; US Department of Health, Education, and Welfare, Public Health Service: Bethesda, MD, USA, 1959.

242. Miao, J.; Chard, L.S.; Wang, Z.; Wang, Y. Syrian Hamster as an Animal Model for the Study on Infectious Diseases. Front. Immunol. 2019, 10, 2329. [CrossRef]

243. Miao, J.X.; Wang, J.Y.; Li, H.Z.; Guo, H.R.; Dunmall, L.S.C.; Zhang, Z.X.; Cheng, Z.G.; Gao, D.L.; Dong, J.Z.; Wang, Z.D.; et al. Promising xenograft animal model recapitulating the features of human pancreatic cancer. World J. Gastroenterol. 2020, $26,4802$. [CrossRef] [PubMed]

244. Zhang, Z.; Zhang, C.; Miao, J.; Wang, Z.; Wang, Z.; Cheng, Z.; Wang, P.; Dunmall, L.S.C.; Lemoine, N.R.; Wang, Y. A TumorTargeted Replicating Oncolytic Adenovirus Ad-TD-nsIL12 as a Promising Therapeutic Agent for Human Esophageal Squamous Cell Carcinoma. Cells 2020, 9, 2438. [CrossRef] [PubMed]

245. Danielsson, M.; Engfeldt, B.; Larsson, B.; Naeslund, C.; Naeslund, J. Effects of therapeutic proton doses on healthy organs in the neck, chest and upper abdomen of the rabbit. Acta Radiol. Ther. Phys. Biol. 1971, 10, 215-224. [CrossRef] [PubMed]

246. Larsson, B.; Leksell, L.; Rexed, B.; Sourander, P. Effect of high energy protons on the spinal cord. Acta Radiol. 1959, 51, 52-64. [CrossRef]

247. Kidd, J.G.; Rous, P. A transplantable rabbit carcinoma originating in a virus-induced papilloma and containing the virus in masked or altered form. J. Exp. Med. 1940, 71, 813-838. [CrossRef]

248. Rous, P.; Beard, J. The progression to carcinoma of virus-induced rabbit papillomas (Shope). J. Exp. Med. 1935, 62, 523-548. [CrossRef]

249. Parvinian, A.; Casadaban, L.C.; Gaba, R.C. Development, growth, propagation, and angiographic utilization of the rabbit VX2 model of liver cancer: A pictorial primer and "how to" guide. Diagn. Interv. Radiol. 2014, 20, 335. [CrossRef]

250. Falkmer, S.; Larsson, B.; Sténson, S. Effects of single dose proton irradiation of normal skin and Vx2 carcinoma in rabbit ears: A comparative investigation with protons and roentgen rays. Acta Radiol. 1959, 52, 217-234. [CrossRef]

251. Naeslund, J.; Sténson, S.; Falkmer, S.; Lindell, A.; Larsson, B.; Svedberg, T. Concerning the Effects of Proton Radiation on Vx2 Carcinoma and Normal Skin in Rabbit Ears; A Preliminary Report. Acta Soc. Medicorum Ups. 1958, 63, 155-159.

252. Engfeldt, B.; Larsson, B.; Naeslund, C.; Naeslund, J.; Tjernberg, B. Effect of single dose or fractionated proton irradiation on pulmonary tissue and Vx2 carcinoma in lung of rabbit. Acta Radiol. Ther. Phys. Biol. 1971, 10, 298-310. [CrossRef] [PubMed]

253. Du, Z.Z.; Ren, H.; Song, J.F.; Zhang, L.F.; Lin, F.; Wang, H.Y. Rabbit model of radiation-induced lung injury. Asian Pac. J. Trop. Med. 2013, 6, 237-241. [CrossRef]

254. Naeslund, J.; Sténson, S.; Larsson, B. Results of proton irradiation of V× 2 carcinoma in the uterus of rabbits. Acta Obstet. Gynecol. Scand. 1959, 38, 563-585. [CrossRef] [PubMed]

255. Danielsson, M.; Engfeldt, B.; Fors, B.; Larsson, B.; Naeslund, J. Effect of High-Energy Protons on $\mathrm{V} \times 2$ Carcinoma Implanted in the Lower Abdominal Wall of the Rabbit: Comparison between single and fractionated irradiation schemes. Acta Obstet. Gynecol. Scand. 1968, 47, 373-389. [CrossRef] [PubMed]

256. Kirsch, D.G.; Grimm, J.; Guimaraes, A.R.; Wojtkiewicz, G.R.; Perez, B.A.; Santiago, P.M.; Anthony, N.K.; Forbes, T.; Doppke, K.; Weissleder, R.; et al. Imaging primary lung cancers in mice to study radiation biology. Int. J. Radiat. Oncol. Biol. Phys. 2010, 76, 973-977. [CrossRef]

257. Kamaruzaman, N.A.; Kardia, E.; Kamaldin, N.; Latahir, A.Z.; Yahaya, B.H. The rabbit as a model for studying lung disease and stem cell therapy. BioMed. Res. Int. 2013, 2013. [CrossRef] 
258. Aravalli, R.N.; Cressman, E.N. Relevance of rabbit VX2 tumor model for studies on human hepatocellular carcinoma: A microRNA-based study. J. Clin. Med. 2015, 4, 1989-1997. [CrossRef]

259. Tobias, C.; Lawrence, J.; Born, J.; McCombs, R.; Roberts, J.; Anger, H.; Low-Beer, B.; Huggins, C. Pituitary irradiation with high-energy proton beams a preliminary report. Cancer Res. 1958, 18, 121-134.

260. Yochmowitz, M.G.; Wood, D.H.; Salmon, Y.L. Delayed Effects of Proton Irradiation in Macaca Mulatta. II. Mortality (15-Year Report); Technical Report; School of Aerospace Medicine Brooks: Air Force Base, TX, USA, 1983.

261. Traynor, J.E.; Casey, H.W. Five-year follow-up of primates exposed to $55 \mathrm{MeV}$ protons. Radiat. Res. 1971, 47, 143-148. [CrossRef] [PubMed]

262. Casey, H.; Coogan, P.; Traynor, J. Late effects of $32 \mathrm{MeV}$ proton irradiation in primates. Radiat. Res. 1969, 39, 634-642. [CrossRef] [PubMed]

263. Bacarella, N.; Ruggiero, A.; Davis, A.T.; Uberseder, B.; Davis, M.A.; Bracy, D.P.; Wasserman, D.H.; Cline, J.M.; Sherrill, C.; Kavanagh, K. Whole body irradiation induces diabetes and adipose insulin resistance in nonhuman primates. Int. J. Radiat. Oncol. Biol. Phys. 2020, 106, 878-886. [CrossRef] [PubMed]

264. DeBo, R.J.; Lees, C.J.; Dugan, G.O.; Caudell, D.L.; Michalson, K.T.; Hanbury, D.B.; Kavanagh, K.; Cline, J.M.; Register, T.C. Late effects of total-body gamma irradiation on cardiac structure and function in male rhesus macaques. Radiat. Res. 2016, 186, 55-64. [CrossRef] [PubMed]

265. Hale, L.P.; Rajam, G.; Carlone, G.M.; Jiang, C.; Owzar, K.; Dugan, G.; Caudell, D.; Chao, N.; Cline, J.M.; Register, T.C.; et al. Late effects of total body irradiation on hematopoietic recovery and immune function in rhesus macaques. PLoS ONE 2019, 14, e0210663. [CrossRef] [PubMed]

266. Lonser, R.R.; Walbridge, S.; Vortmeyer, A.O.; Pack, S.D.; Nguyen, T.T.; Gogate, N.; Olson, J.J.; Akbasak, A.; Bobo, R.H.; Goffman, T.; et al. Induction of glioblastoma multiforme in nonhuman primates after therapeutic doses of fractionated whole-brain radiation therapy. J. Neurosurg. 2002, 97, 1378-1389. [CrossRef]

267. Latanov, A.; Tereschenko, L.; Ostrovsky, M. Influence of Cranial Irradiation with High-Energy Protons on the Visuomotor Behavior in Monkeys. Dokl. Biol. Sci. 2019, 487, 95-97. [CrossRef]

268. Williams, J.P.; Brown, S.L.; Georges, G.E.; Hauer-Jensen, M.; Hill, R.P.; Huser, A.K.; Kirsch, D.G.; MacVittie, T.J.; Mason, K.A.; Medhora, M.M.; et al. Animal models for medical countermeasures to radiation exposure. Radiat. Res. 2010, 173, 557-578. [CrossRef]

269. Sanzari, J.K.; Krigsfeld, G.S.; Shuman, A.L.; Diener, A.K.; Lin, L.; Mai, W.; Kennedy, A.R. Effects of a granulocyte colony stimulating factor, Neulasta, in mini pigs exposed to total body proton irradiation. Life Sci. Space Res. 2015, 5, 13-20. [CrossRef] [PubMed]

270. Miot-Noirault, E.; Akoka, S.; Hoffschir, D.; Pontvert, D.; Gaboriaud, G.; Alapetite, C.; Fetissof, F.; Le Pape, A. Potential of T2 relaxation time measurements for early detection of radiation injury to the brain: Experimental study in pigs. Am. J. Neuroradiol. 1996, 17, 907-912. [PubMed]

271. Vozenin, M.C.; De Fornel, P.; Petersson, K.; Favaudon, V.; Jaccard, M.; Germond, J.F.; Petit, B.; Burki, M.; Ferrand, G.; Patin, D.; et al. The advantage of FLASH radiotherapy confirmed in mini-pig and cat-cancer patients. Clin. Cancer Res. 2019, $25,35-42$. [CrossRef]

272. Momeni, M.; Cahill, T.; Horn, P.L. Proton Irradiation of Beagle Eyes. I. Si (Li) and Thermoluminescent Dosimetry of 20, 35 , and 45 MeV Protons. Radiat. Res. 1973, 53, 15-23. [CrossRef]

273. Horn, P.L.; Shifrine, M. Proton Irradiation of Beagle Eyes: II. Clinical and Histopathologic Observations for 35 MeV Protons. Radiat. Res. 1973, 53, 255-266. [CrossRef]

274. Nolan, M.W.; Kent, M.S.; Boss, M.K. Emerging translational opportunities in comparative oncology with companion canine cancers: Radiation oncology. Front. Oncol. 2019, 9, 1291. [CrossRef] [PubMed]

275. LeBlanc, A.K.; Mazcko, C.; Brown, D.E.; Koehler, J.W.; Miller, A.D.; Miller, C.R.; Bentley, R.T.; Packer, R.A.; Breen, M.; Boudreau, C.E.; et al. Creation of an NCI comparative brain tumor consortium: Informing the translation of new knowledge from canine to human brain tumor patients. Neuro Oncol. 2016, 18, 1209-1218. [CrossRef]

276. Mayer-Stankeová, S.; Fidel, J.; Wergin, M.C.; Hauser, B.; Sumova, A.; Goitein, G.; Pedroni, E.; Lomax, A.J.; Schneider, U.; Blattmann, H.; et al. Proton spot scanning radiotherapy of spontaneous canine tumors. Vet. Radiol. Ultrasound 2009, 50, 314-318. [CrossRef]

277. Porrello, A.; Cardelli, P.; Spugnini, E. Pet models in cancer research: General principles. J. Exp. Clin. Cancer Res. CR 2004, 23, 181-193.

278. Gordon, I.K.; Khanna, C. Modeling opportunities in comparative oncology for drug development. ILAR J. 2010, 51, 214-220. [CrossRef]

279. Gordon, I.; Paoloni, M.; Mazcko, C.; Khanna, C. The Comparative Oncology Trials Consortium: Using Spontaneously Occurring Cancers in Dogs to Inform the Cancer Drug Development Pathway. PLoS Med. 2009, 6, e1000161. [CrossRef] [PubMed]

280. Schuemann, J.; McNamara, A.L.; Ramos-Méndez, J.; Perl, J.; Held, K.D.; Paganetti, H.; Incerti, S.; Faddegon, B. TOPAS-nBio: An Extension to the TOPAS Simulation Toolkit for Cellular and Sub-cellular Radiobiology. Radiat. Res. 2018, 191, 125. [CrossRef]

281. McMahon, S.J. The linear quadratic model: Usage, interpretation and challenges. Phys. Med. Biol. 2018, 64, 01TR01. [CrossRef] [PubMed]

282. McMahon, S.J.; Prise, K.M. Mechanistic modelling of radiation responses. Cancers 2019, 11, 205. [CrossRef] 
283. Uehara, S.; Nikjoo, H.; Goodhead, D.T. Cross-sections for water vapour for the Monte Carlo electron track structure code from 10 $\mathrm{eV}$ to the MeV region. Phys. Med. Biol. 1993, 38, 1841-1858. [CrossRef]

284. Nikjoo, H.; Goodhead, D.T.; Charlton, D.E.; Paretzke, H.G. Energy deposition in small cylindrical targets by ultrasoft X-rays. Phys. Med. Biol. 1989, 34, 691-705. [CrossRef] [PubMed]

285. Plante, I.; Ponomarev, A.L.; Cucinotta, F.A. Calculation of the energy deposition in nanovolumes by protons and HZE particles: Geometric patterns of initial distributions of DNA repair foci. Phys. Med. Biol. 2013, 58, 6393-6405. [CrossRef]

286. Sato, T.; Iwamoto, Y.; Hashimoto, S.; Ogawa, T.; Furuta, T.; Abe, S.i.; Kai, T.; Tsai, P.E.; Matsuda, N.; Iwase, H.; et al. Features of Particle and Heavy Ion Transport code System (PHITS) version 3.02. J. Nucl. Sci. Technol. 2018, 55, 684-690. [CrossRef]

287. Friedland, W.; Dingfelder, M.; Kundrát, P.; Jacob, P. Track structures, DNA targets and radiation effects in the biophysical Monte Carlo simulation code PARTRAC. Mutat. Res. Mol. Mech. Mutagen. 2011, 711, 28-40. [CrossRef] [PubMed]

288. Incerti, S.; Baldacchino, G.; Bernal, M.; Capra, R.; Champion, C.; Francis, Z.; Guèye, P.; Mantero, A.; Mascialino, B.; Moretto, P.; et al. THE GEANT4-DNA PROJECT. Int. J. Model. Simul. Sci. Comput. 2010, 1, 157-178. [CrossRef]

289. Nikjoo, H.; Uehara, S.; Emfietzoglou, D.; Cucinotta, F. Track-structure codes in radiation research. Radiat. Meas. 2006, 41, 1052-1074. [CrossRef]

290. Agostinelli, S.; Allison, J.; Amako, K.; Apostolakis, J.; Araujo, H.; Arce, P.e.a. Geant4-A simulation toolkit. Nucl. Instrum. Methods Phys. Res. Sect. Accel. Spectrometers Detect. Assoc. Equip. 2003, 506, 250-303. [CrossRef]

291. Battistoni, G.; Bauer, J.; Boehlen, T.T.; Cerutti, F.; Chin, M.P.W.; Dos Santos Augusto, R.; Ferrari, A.; Ortega, P.G.; Kozowska, W.; Magro, G.; et al. The FLUKA Code: An Accurate Simulation Tool for Particle Therapy. Front. Oncol. 2016, 6. [CrossRef]

292. Kreipl, M.S.; Friedland, W.; Paretzke, H.G. Time- and space-resolved Monte Carlo study of water radiolysis for photon, electron and ion irradiation. Radiat. Environ. Biophys. 2009, 48, 11-20. [CrossRef] [PubMed]

293. Cucinotta, F.A.; Pluth, J.M.; Anderson, J.A.; Harper, J.V.; O’Neill, P. Biochemical Kinetics Model of DSB Repair and Induction of gamma-H2AX Foci by Non-homologous End Joining. Radiat. Res. 2008, 169, 214-222. [CrossRef]

294. Belov, O.V.; Krasavin, E.A.; Lyashko, M.S.; Batmunkh, M.; Sweilam, N.H. A quantitative model of the major pathways for radiation-induced DNA double-strand break repair. J. Theor. Biol. 2015, 366, 115-130. [CrossRef] [PubMed]

295. Sakata, D.; Belov, O.; Bordage, M.C.; Emfietzoglou, D.; Guatelli, S.; Inaniwa, T.; Ivanchenko, V.; Karamitros, M.; Kyriakou, I.; Lampe, N.; et al. Fully integrated Monte Carlo simulation for evaluating radiation induced DNA damage and subsequent repair using Geant4-DNA. Sci. Rep. 2020, 10, 20788. [CrossRef] [PubMed]

296. Carlson, D.J.; Stewart, R.D.; Semenenko, V.A.; Sandison, G.A. Combined Use of Monte Carlo DNA Damage Simulations and Deterministic Repair Models to Examine Putative Mechanisms of Cell Killing. Radiat. Res. 2008, 169, 447-459. [CrossRef] [PubMed]

297. Friedland, W.; Jacob, P.; Kundrát, P. Stochastic Simulation of DNA Double-Strand Break Repair by Non-homologous End Joining Based on Track Structure Calculations. Radiat. Res. 2010, 173, 677-688. [CrossRef] [PubMed]

298. Henthorn, N.T.; Warmenhoven, J.W.; Sotiropoulos, M.; Mackay, R.I.; Kirkby, N.F.; Kirkby, K.J.; Merchant, M.J. In Silico NonHomologous End Joining Following Ion Induced DNA Double Strand Breaks Predicts That Repair Fidelity Depends on Break Density. Sci. Rep. 2018, 8, 2654. [CrossRef]

299. Warmenhoven, J.W.; Henthorn, N.T.; Ingram, S.P.; Chadwick, A.L.; Sotiropoulos, M.; Korabel, N.; Fedotov, S.; Mackay, R.I.; Kirkby, K.J.; Merchant, M.J. Insights into the non-homologous end joining pathway and double strand break end mobility provided by mechanistic in silico modelling. DNA Repair 2020, 85, 102743. [CrossRef]

300. Henthorn, N.T.; Warmenhoven, J.W.; Sotiropoulos, M.; Mackay, R.I.; Kirkby, K.J.; Merchant, M.J. Nanodosimetric Simulation of Direct Ion-Induced DNA Damage Using Different Chromatin Geometry Models. Radiat. Res. 2017, 188, 770-783. [CrossRef] [PubMed]

301. Dos Santos, M.; Villagrasa, C.; Clairand, I.; Incerti, S. Influence of the DNA density on the number of clustered damages created by protons of different energies. Nucl. Instrum. Methods Phys. B Res. Sect. Beam Interact. Mater. Atoms 2013, 298, 47-54. [CrossRef]

302. Friedland, W.; Schmitt, E.; Kundrát, P.; Dingfelder, M.; Baiocco, G.; Barbieri, S.; Ottolenghi, A. Comprehensive track-structure based evaluation of DNA damage by light ions from radiotherapy-relevant energies down to stopping. Sci. Rep. 2017, 7, 45161. [CrossRef] [PubMed]

303. Smith, E.A.K.; Henthorn, N.T.; Warmenhoven, J.W.; Ingram, S.P.; Aitkenhead, A.H.; Richardson, J.C.; Sitch, P.; Chadwick, A.L.; Underwood, T.S.A.; Merchant, M.J.; et al. In Silico Models of DNA Damage and Repair in Proton Treatment Planning: A Proof of Concept. Sci. Rep. 2019, 9, 19870. [CrossRef] [PubMed]

304. Henthorn, N.T.; Warmenhoven, J.W.; Sotiropoulos, M.; Aitkenhead, A.H.; Smith, E.A.K.; Ingram, S.P.; Kirkby, N.F.; Chadwick, A.; Burnet, N.G.; Mackay, R.I.; et al. Clinically relevant nanodosimetric simulation of DNA damage complexity from photons and protons. RSC Adv. 2019, 9, 6845-6858. [CrossRef]

305. Chadwick, K.; Leenhouts, H. Molecular Theory of Cell Survival; Technical Report; Instituut voor Toepassing van Atoomenergie in de Landbouw: Wageningen, The Netherlands, 1973.

306. Kellerer, A.M.; Rossi, H.H. A generalized formulation of dual radiation action. Radiat. Res. 1978, 75, 471-488. [CrossRef]

307. Tobias, C.A.; Blakely, E.A.; Ngo, F.Q.H.; Yang, T.C. The Repair-Misrepair Model of Cell Survival. Radiat Res. Suppl. 1980,8, 77-95. [CrossRef]

308. Goodhead, D.T. Saturable repair models of radiation action in mammalian cells. Radiat. Res. 1985, 104, S58-S67. [CrossRef] 
309. Curtis, S.B. Lethal and potentially lethal lesions induced by radiation-A unified repair model. Radiat. Res. 1986, 106, 252-270. [CrossRef]

310. Bodgi, L.; Canet, A.; Pujo-Menjouet, L.; Lesne, A.; Victor, J.M.; Foray, N. Mathematical models of radiation action on living cells: From the target theory to the modern approaches. A historical and critical review. J. Theor. Biol. 2016, 394, 93-101. [CrossRef]

311. Koch, R.A.; Harmel, C.; Alber, M.; Bahn, E. A framework for automated time-resolved analysis of cell colony growth after irradiation. Phys. Med. Biol. 2021, 66, 035017. [CrossRef] [PubMed]

312. McNamara, A.; Willers, H.; Paganetti, H. Modelling variable proton relative biological effectiveness for treatment planning. Br. J. Radiol. 2020, 93, 20190334. [CrossRef]

313. Elsässer, T.; Weyrather, W.K.; Friedrich, T.; Durante, M.; Iancu, G.; Krämer, M.; Kragl, G.; Brons, S.; Winter, M.; Weber, K.J.; et al Quantification of the relative biological effectiveness for ion beam radiotherapy: Direct experimental comparison of proton and carbon ion beams and a novel approach for treatment planning. Int. J. Radiat. Oncol. Biol. Phys. 2010, 78, 1177-1183. [CrossRef]

314. Hawkins, R.B. A microdosimetric-kinetic model for the effect of non-Poisson distribution of lethal lesions on the variation of RBE with LET. Radiat. Res. 2003, 160, 61-69. [CrossRef]

315. McNamara, A.L.; Schuemann, J.; Paganetti, H. A phenomenological relative biological effectiveness (RBE) model for proton therapy based on all published in vitro cell survival data. Phys. Med. Biol. 2015, 60, 8399. [CrossRef] [PubMed]

316. Wedenberg, M.; Lind, B.K.; Hårdemark, B. A model for the relative biological effectiveness of protons: The tissue specific parameter $\alpha / \beta$ of photons is a predictor for the sensitivity to LET changes. Acta Oncol. 2013, 52, 580-588. [CrossRef] [PubMed]

317. Carabe-Fernandez, A.; Dale, R.G.; Jones, B. The incorporation of the concept of minimum RBE (RBE min) into the linear-quadratic model and the potential for improved radiobiological analysis of high-LET treatments. Int. J. Radiat. Biol. 2007, 83, 27-39. [CrossRef] [PubMed]

318. Karolak, A.; Markov, D.A.; McCawley, L.J.; Rejniak, K.A. Towards personalized computational oncology: From spatial models of tumour spheroids, to organoids, to tissues. J. R. Soc. Interface 2018, 15, 20170703. [CrossRef] [PubMed]

319. Marcu, L.G.; Harriss-Phillips, W.M. In silico modelling of treatment-induced tumour cell kill: Developments and advances. Comput. Math. Methods Med. 2012, 2012. [CrossRef]

320. Roberts, S.A.; Hendry, J.H.; Potten, C.S. Intestinal crypt clonogens: A new interpretation of radiation survival curve shape and clonogenic cell number. Cell Prolif. 2003, 36, 215-231. [CrossRef]

321. Maj, J.G.; Paris, F.; Haimovitz-Friedman, A.; Venkatraman, E.; Kolesnick, R.; Fuks, Z. Microvascular function regulates intestinal crypt response to radiation. Cancer Res. 2003, 63, 4338-4341. [PubMed]

322. Bahn, E.; van Heerden, M.; Gueulette, J.; Slabbert, J.P.; Shaw, W.; Debus, J.; Alber, M. Reserve stem cell population in intestinal crypts found to be consistently small by analysis of in vivo clonogenic assays with a biomathematical dynamic model. Radiother. Oncol. 2018, 129, 595-599. [CrossRef] [PubMed]

323. Bahn, E.; van Heerden, M.; Sachse, K.N.; Gueulette, J.; Slabbert, J.P.; Alber, M.; Shaw, W. Volume-dependent dose-response of the intestinal stem cell niche and lymphoid tissue. Radiother. Oncol. 2020, 150, 51-56. [CrossRef] [PubMed]

324. Zaider, M.; Hanin, L. Tumor control probability in radiation treatment. Med. Phys. 2011, 38, 574-583. [CrossRef]

325. Hill, R.P. The changing paradigm of tumour response to irradiation. Br. J. Radiol. 2017, 90, 20160474. [CrossRef]

326. Hopewell, J.; Morris, A.; Dixon-Brown, A. The influence of field size on the late tolerance of the rat spinal cord to single doses of X rays. Br. J. Radiol. 1987, 60, 1099-1108. [CrossRef]

327. Bentzen, S.M.; Constine, L.S.; Deasy, J.O.; Eisbruch, A.; Jackson, A.; Marks, L.B.; Ten Haken, R.K.; Yorke, E.D. Quantitative Analyses of Normal Tissue Effects in the Clinic (QUANTEC): An introduction to the scientific issues. Int. J. Radiat. Oncol. Biol. Phys. 2010, 76, S3-S9. [CrossRef]

328. Schultheiss, T.E.; Higgins, E.M.; El-Mahdi, A.M. The latent period in clinical radiation myelopathy. Int. J. Radiat. Oncol. Biol. Phys. 1984, 10, 1109-1115. [CrossRef]

329. Bentzen, S.M. Preventing or reducing late side effects of radiation therapy: Radiobiology meets molecular pathology. Nat. Rev. Cancer 2006, 6, 702-713. [CrossRef] [PubMed]

330. Lyman, J.T. Complication probability as assessed from dose-volume histograms. Radiat. Res. 1985, 104, S13-S19. [CrossRef]

331. Niemierko, A. Reporting and analyzing dose distributions: A concept of equivalent uniform dose. Med. Phys. 1997, 24, 103-110. [CrossRef]

332. Schultheiss, T.E.; Orton, C.G.; Peck, R. Models in radiotherapy: Volume effects. Med. Phys. 1983, 10, 410-415. [CrossRef]

333. Niemierko, A.; Goitein, M. Modeling of normal tissue response to radiation: The critical volume model. Int. J. Radiat. Oncol. Biol. Phys. 1993, 25, 135-145. [CrossRef]

334. Jackson, A.; Kutcher, G.; Yorke, E. Probability of radiation-induced complications for normal tissues with parallel architecture subject to non-uniform irradiation. Med. Phys. 1993, 20, 613-625. [CrossRef]

335. Alber, M.; Belka, C. A normal tissue dose response model of dynamic repair processes. Phys. Med. Biol. 2005, 51, 153. [CrossRef]

336. Trott, K.R.; Doerr, W.; Facoetti, A.; Hopewell, J.; Langendijk, J.; van Luijk, P.; Ottolenghi, A.; Smyth, V. Biological mechanisms of normal tissue damage: Importance for the design of NTCP models. Radiother. Oncol. 2012, 105, 79-85. [CrossRef]

337. Jäkel, O.; Krämer, M.; Schulz-Ertner, D.; Heeg, P.; Karger, C.; Didinger, B.; Nikoghosyan, A.; Debus, J. Treatment planning for carbon ion radiotherapy in Germany: Review of clinical trials and treatment planning studies. Radiother. Oncol. 2004, 73, S86-S91. [CrossRef] 
338. Inaniwa, T.; Kanematsu, N.; Matsufuji, N.; Kanai, T.; Shirai, T.; Noda, K.; Tsuji, H.; Kamada, T.; Tsujii, H. Reformulation of a clinical-dose system for carbon-ion radiotherapy treatment planning at the National Institute of Radiological Sciences, Japan. Phys. Med. Biol. 2015, 60, 3271. [CrossRef] [PubMed]

339. Langendijk, J.A.; Lambin, P.; De Ruysscher, D.; Widder, J.; Bos, M.; Verheij, M. Selection of patients for radiotherapy with protons aiming at reduction of side effects: The model-based approach. Radiother. Oncol. 2013, 107, 267-273. [CrossRef] [PubMed]

340. Bauer, J.; Bahn, E.; Harrabi, S.; Herfarth, K.; Debus, J.; Alber, M. How can scanned proton beam treatment planning for low-grade glioma cope with increased distal RBE and locally increased radiosensitivity for late MR-detected brain lesions? Med. Phys. 2021, 48, 1497-1507. [CrossRef] [PubMed]

341. Engeseth, G.M.; He, R.; Mirkovic, D.; Yepes, P.; Mohamed, A.S.R.; Stieb, S.; Fuller, C.D.; Wu, R.; Zhang, X.; Hysing, L.B.; et al. Mixed effect modelling of dose and Linear Energy Transfer correlations with brain image changes after intensity modulated proton therapy for skull base head and neck cancer. Int. J. Radiat. Oncol. Biol. Phys. 2021. [CrossRef]

342. Skaarup, M.; Lundemann, M.J.; Darkner, S.; Jørgensen, M.; Marner, L.; Mirkovic, D.; Grosshans, D.; Peeler, C.; Mohan, R.; Vogelius, I.R.; et al. A framework for voxel-based assessment of biological effect after proton radiotherapy in pediatric brain cancer patients using multi-modal imaging. Med. Phys. 2021. [CrossRef] [PubMed] 